\title{
EVALUATION OF THE EFFECTS OF BREAK NOZZLE CONFIGURATION IN THE SEMISCALE MOD-1 SYSTEM
}

\author{
ROBERT G. HANSON
}

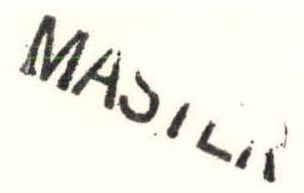

August 1977

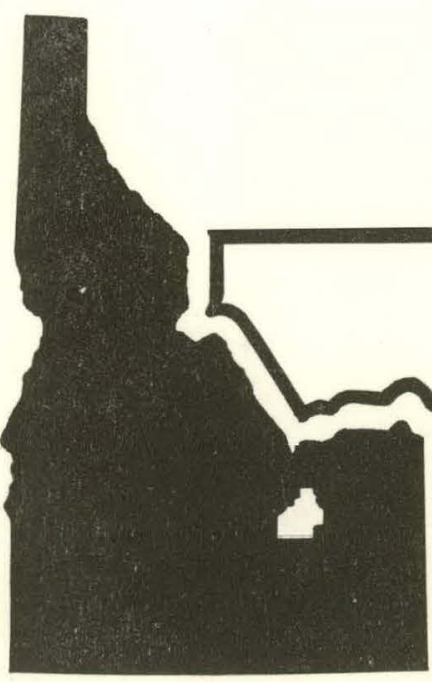

EG\&G Idaho, Inc.

IDAHO NATIONAL ENGINEERING LABORATORY

ENERGY RESEARCH AND DEVELOPMENT ADMINISTRATION

IDAHO OPERATIONS OFFICE UNDER CONTRACT EY-76-C-07-1570 


\section{DISCLAIMER}

This report was prepared as an account of work sponsored by an agency of the United States Government. Neither the United States Government nor any agency Thereof, nor any of their employees, makes any warranty, express or implied, or assumes any legal liability or responsibility for the accuracy, completeness, or usefulness of any information, apparatus, product, or process disclosed, or represents that its use would not infringe privately owned rights. Reference herein to any specific commercial product, process, or service by trade name, trademark, manufacturer, or otherwise does not necessarily constitute or imply its endorsement, recommendation, or favoring by the United States Government or any agency thereof. The views and opinions of authors expressed herein do not necessarily state or reflect those of the United States Government or any agency thereof. 


\section{DISCLAIMER}

Portions of this document may be illegible in electronic image products. Images are produced from the best available original document. 
Printed in the United States of America

Available from

National Technical Information Service

U.S. Department of Commerce

5285 Port Royal Road

Springfield, Virginia 22161

Price: Printed Copy $\$ 4.00$; Microfiche $\$ 3.00$

$$
4,50
$$

"The NRC will make available data tapes and operational computer codes on research programs dealing with postulated loss-of-coolant accidents in light water reactors. Persons requesting this information must reimburse the NRC contractors for their expenses in preparing copies of the data tapes and the operational computer codes. Requests should be submitted to the Research Applications Branch, Office of Nuclear Regulatory Research, Nuclear Regulatory Commission, Washington, D.C. 20555."

This report was prepared as an account of work sponsored by the United States Government. Neither the United States nor the Energy Research and Development Administration, nor the Nuclear Regulatory Commission, nor any of their employees, nor any of their contractors, subcontractors, or their employees, makes any warranty, express or implied, or assumes any legal liability or responsibility for the accuracy, completeness or usefulness of any information, apparatus, product or process disclosed, or represents that its use would not infringe privately owned rights. 
TREE-NUREG-1118

\section{EVALUATION OF THE EFFECTS OF BREAK NOZZLE}

\section{CONFIGURATION IN THE SEMISCALE MOD-1 SYSTEM}

Approved:
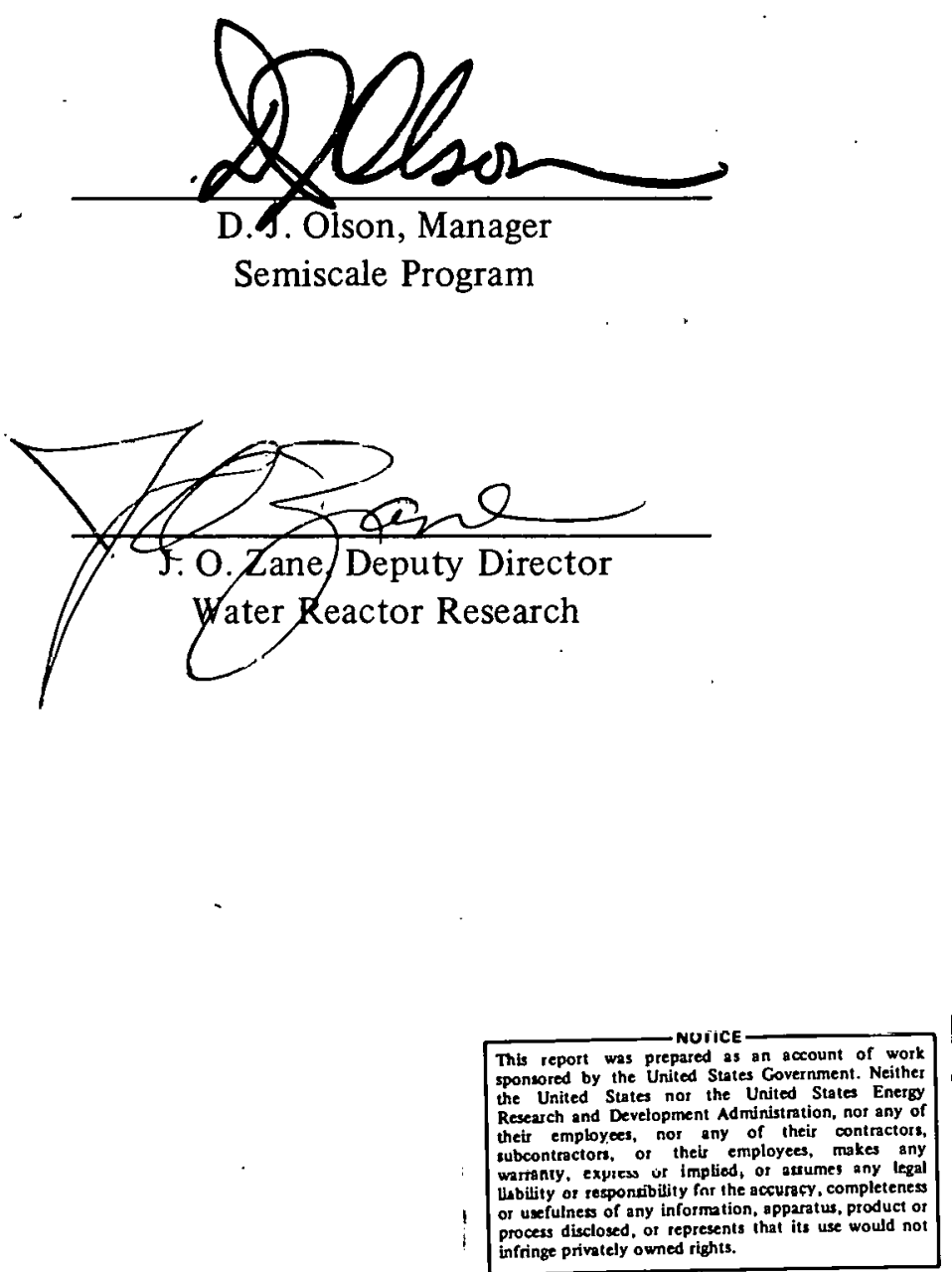
EVALUATION OF THE EFFECTS OF BREAK NOZZLE CONFIGURATION IN THE SEMISCALE MOD-1 SYSTEM

by

Robert G. Hanson

EG\&G IDAHO, INC.

August 1977

PREPARED FOR THE

U.S. NUCLEAR REGULATORY COMMISSION

AND

ENERGY RESEARCH AND DEVELOPMENT ADMINISTRATION

IDAHO OPERATIONS OFFICE

UNDER CONTRACT NO. EY-76-C-07-1570 


\section{ACKNOWLEDGMENTS}

The author expresses his thanks to the personnel of the Semiscalc Facilities and Uperations Branch for their etforts in conducting the tests and gathering the data, to the personnel of the Test Engineering Branch for verification and documentation of the data, to the personnel of the Semiscale Data Systems Branch for providing data processing support, to K.A. Dietz for her editing contribution to improve document quality, and to Kerry Coughlan and Elinor Witbeck for their typing and proofreading efforts. 


\begin{abstract}
The Semiscale Mod-1 Program has utilized two different break nozzle configurations in the test system. An evaluation has been made to determine the effect these break nozzle configurations have on system thermal-hydraulic response during a $200 \%$ double-ended cold leg break loss-of-coolant accident simulation. The first nozzle was a convergent-divergent nozzle (Henry nozzle) and the second, an elongated constant area throat nozzle. Analysis is confined primarily to system response phenomena observed to be affected by the nozzle configuration and concentrates on the fluid response at the break and the resulting core behavior during subcooled and saturated blowdown. The evaluation shows that considerable difference in system response occurs as a result of the difference in break nozzle configuration. The elongated throat nozzle was scaled from the Loss-of-Fluid Test (LOFT) nozzle geometry and since the LOFT counterpart tests were designed to provide results for the LOFT Program, the elongated throat nozzle was used in the subsequent LOFT counterpart tests.
\end{abstract}




\section{SUMMARY}

The Semiscale experimental program conducted by EG\&G Idaho, Inc. is part of the overall U.S. Nuclear Regulatory Commission and Energy Research and Development Administration sponsored research and development program to investigate the behavior of the pressurized water reactor system during a hypothesized loss-of-coolant accident (LOCA). The Semiscale Mod-1 Program provides transient thermal-hydraulic data from a simulated LOCA which can be used to evaluate the adequacy of analy tical models developed for LOCA analysis. The Semiscale Mod-1 system is a small scale experimental nonnuclear system in which nuclear heating is simulated by an electrically heated core. The system has an intact loop with an active steam generator and pump and a broken loop with passive simulators for the steam generator and pump. The broken loop has break assemblies which initiatc the LOCA event.

Previous analysis in the Semiscale Mod- 1 Program has indicated that the system response has varied as the break flows have differed. During the course of testing in the Semiscale Mod-1 Program, two different nozzle configurations have been used in the broken loop break assemblies. The analysis presented herein was performed to assess the effect that the different break nozzle configurations have on the thermal-hydraulic system response during a simulated $200 \%$ double-ended cold leg break.

The first nozzle was a convergent-divergent nozzle with a short constant area throat. The second nozzle had a slight convergent section followed by an elongated constant area throat with a step area increase downstream. The two nozzle configurations were tested under the same boundary conditions and initial conditions with the same system configuration.

Comparison of the results from tests with the two different break nozzle configurations indicates that nozzle configuration directly influences system response. The break flow was significantly influenced. The flow rate through the elongated throat nozzle was less than that observed in the Henry nozzle during the subcooled portion of blowdown. Due to this reduced flow in the elongated throat nozzle, the transition from subcooled to saturated blowdown was delayed $0.5 \mathrm{sec}$.

The lower break flow rate through the elongated throat nozzle resulted in a lower core inlet flow reversal than was observed in the test ulitizing the Henry nozzle. For the lower reversed core flow rate, less heat was removed from the core, causing a shift to earlier departures from nucleate boiling (DNB) than were observed when the Henry nozzle was utilized.

The relation between break flow, core flow reversal, and core DNB response early in blowdown was supported by other Semiscale Mod-1 test data and by the calculations from a RELAP4 computer code core model. 
The results of this evaluation indicate that the core thermal-hydraulic response is significantly affected by the break flow differences resulting from the two different break nozzle configurations. Since the elongated throat nozzle was scaled from the break geometry in the LOFT nozzle and the LOFT counterpart tests were designed to provide the LOFT Program with representative and comparable data, the elongated throat nozzle was used in subsequent LOFT counterpart tests. 


\section{CONTENTS}

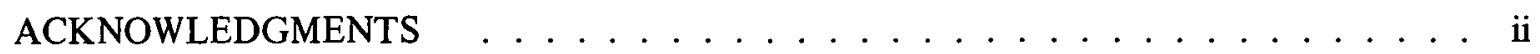

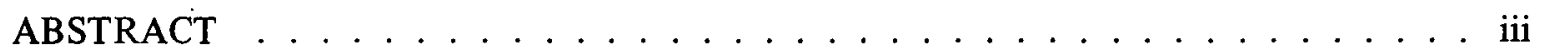

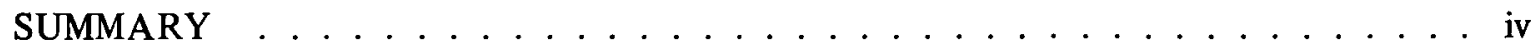

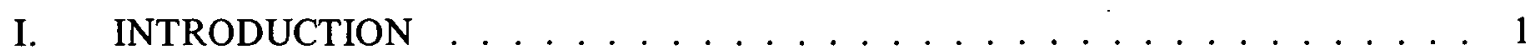

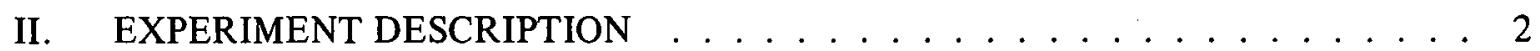

III. EVALUATION OF THE BREAK NOZZLE CONFIGURATION

EFFECT ON THE SYSTEM . . . . . . . . . . . . . . . . 6

1. EVALUATION OF THE BREAK BEHAVIOR .......... 6

2. CORE RESPONSE EARLY IN BLOWDOWN . . . . . . . . . . . . 10

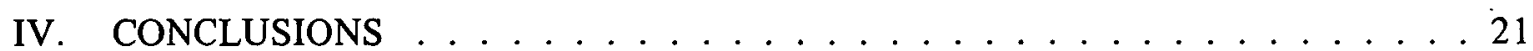

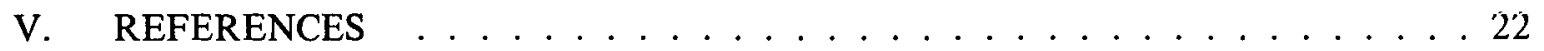

APPENDIX A - RELAP4 CORE MODEL DESCRIPTION . . . . . . . . . . . 23

REFERENCES $\ldots \ldots \ldots \ldots \ldots \ldots$

FIGURES

1. Henry nozzle ........................ . . 2

2. Elongated throat nozzle .................... 3

3. Semiscale Mod-1 system configuration ................ 4

4. Break flow rate during early blowdown . . . . . . . . . . . . 7

5. Fluid temperature upstream of the break nozzle $(\mathrm{TFB}-23) \ldots \ldots \ldots \ldots \ldots$. . . . . . . . . . . . . . . . . . . . .

6. Pressure upstream of the break nozzle $(\mathrm{PB}-23) \ldots \ldots \ldots$

7. Throat pressure in the break nozzle (PB-CN1) $\because \ldots \ldots . . \ldots . . . .99$ 
8. Pressure history in the elongated throat nozzle .............. 9

9. Core inlet flow rate during early blowdown

(FTV-CORE-IN) . . . . . . . . . . . . . . . . . 11

10. Heater rod response at localion TH-E5-20

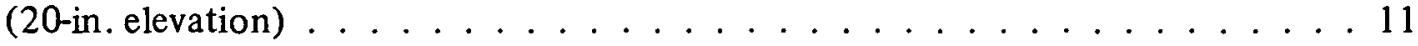

11. Heater rod response at location TH-D6-25

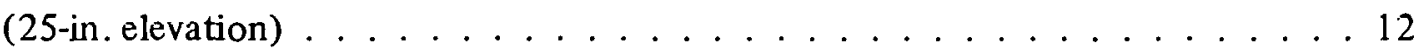

12. Heater rod response at location TH-E4-28

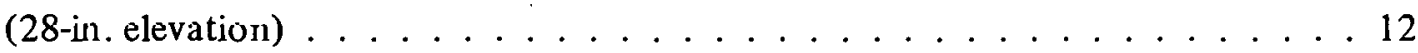

13. Core flow during early blowdown . . . . . . . . . . . . . . . 14

14. Fluid quality in the core for the Henry

nozzle test . . . . . . . . . . . . . . . . 17

15. Fluid quality in the core for the elongated

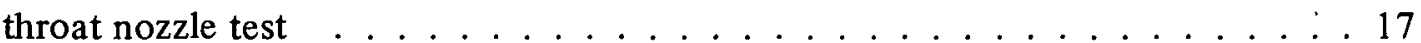

16. RELAP4 calculation of mass flow in the core

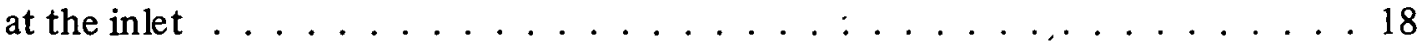

17. RELAP4 calculation of mass flow in the core at the 27 -in. elevation . . . . . . . . . . . . . 18

18. RELAP4 calculation of mass flow in the core at the 52 -in. elevation . . . . . . . . . . . . . . . . . 19

19. Mass flow at the core inlet .................... 20

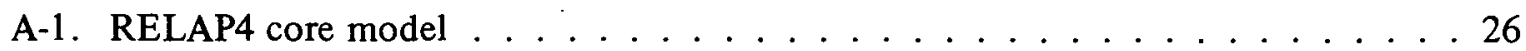

\section{TABLES}

I. Comparison of Maximum Rod Cladding Temperatures for the

Henry Nozzle and the Elongated Throat Nozzle . . . . . . . . . . . . . . . 13

II. Times to DNB for the Henry Nozzle, Elongated

Throat Nozzle, and Test S-05-5 . . . . . . . . . . . 15 
A-1. RELAP4 Control Volume Description . . . . . . . . . . . . . . . . 27

A-2. RELAP4 Junction Description . . . . . . . . . . . . . . . 27 


\section{EVALUATION OF THE EFFECTS OF BREAK NOZZLE CONFIGURATION IN THE SEMISCALE MOD-1 SYSTEM}

\section{INTRODUCTION}

The Semiscale experimental program conducted by EG\&G Idaho, Inc. is part of the overall U.S. Nuclear Regulatory Commission (NRC) and Energy Research and Development Administration (ERDA) sponsored research and development program to investigate the behavior of the pressurized water reactor (PWR) system during a hypothesized loss-ofcoolant accident (LOCA). The Semiscale Mod-1 Program is intended to provide transient thermal-hydraulic data from a simulated LOCA using a small scale experimental nonnuclear system. The Semiscale Mod-1 Program is a major contributor of experimental data that provide a means of evaluating the adequacy of the overall system analytical models as well as the models of the individual system components. Selected experimental data from this program will be used to aid other ERDA and NRC sponsored experimental programs, such as the Loss-of-Fluid Test (LOFT) Program ${ }^{[1]}$, in optimizing test series, selecting test parameters, and evaluating results.

Previous work in the Semiscale Mod-1 experimental program has shown that the flow rates at the break nozzles have major influence on the response of the system. Since the break nozzle configuration may influence the break flow rate, an analysis was performed to evaluate the effect of break nozzle configuration on the break flow rate and the rest of the system.

Two different nozzle geometries have been used in the Semiscale Mod-1 tests. One of the break nozzles was a convergent-divergent flow nozzle (Henry nozzle); the other nozzle (elongated throat nozzle) consisted of a slight converging section followed by an elongated constant area throat section. These two nozzle configurations were tested with the same experimental configuratiun ulilizing the same initial and boundary conditions.

The experimental system is briefly described in Section II of this report. Section II also includes a detailed description of the Henry nozzle and the elongated throat nozzle. Section III presents the evaluation of the effect of the nozzle configuration ${ }^{[a]}$ on the system response. Section IV presents the significant conclusion resulting from the nozzle evaluation. Appendix A presents a description of the RELAP4 ${ }^{[2]}$ core model and how it was utilized in this study.

[a] On the data graphs (following Figure 3), the Henry nozzle data do not begin at zero time due to the design of the data processing subroutine used to plot the data. 


\section{EXPERIMENT DESCRIPTION}

Two break nozzle configurations have been used in the Semiscale Mod-1 experimental system. These nozzle configurations and the system in which they were utilized are described briefly later in this section. The two nozzles that were used, and evaluated in this report, are the-convergent-divergent Henry nozzle and the elongated throat nozzle.

The convergent-divergent Henry nozzle, shown in Figure 1, is the configuration used at the break for all previous Semiscale Mod-1 system experimental work. This nozzle consists of a convergent region which extends from the upstream cross-sectional area to the throat area. The constant area throat secliun is $0.985 \mathrm{in}$. in longth followed by a lnng divergent section. 'I'he Henry nozzle has fuus peessure tap locatione. Two of the pressure taps, designated PB-CN1 and PB-CN2, arc located in the throat section. Pressure taps designated $\mathrm{PB}-\mathrm{CN} 3$ and $\mathrm{PB}-\mathrm{CN} 4$ are located at the beginning and near the end of the divergent section, respectively. Figure 1 shows the pressure tap locations and their rotational orientation.

The elongated throat nozzle is shown in Figure 2. The elongated throat nozzle configuration was designed as a scaled version of the LOFT system break nozzle geometry. The elongated throat nozzle has a step reduction in cross-sectional area at the nozzle entrance followed by a convergent section. The throat areas for the elongated throat nozzle and the Henry nozzle were the same in order to maintain the break size specified for the

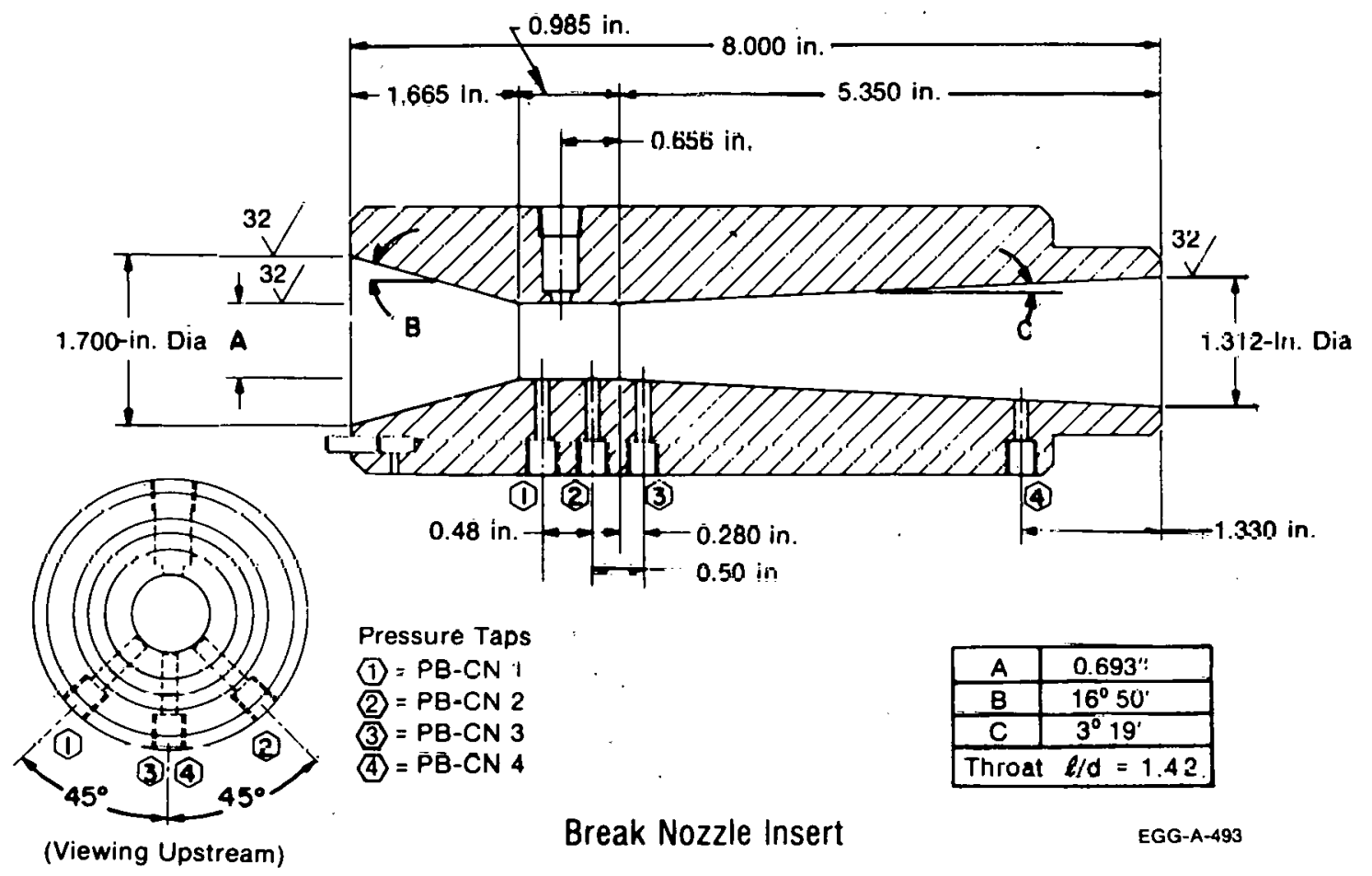

Fig. 1 Henry.nozzle. 


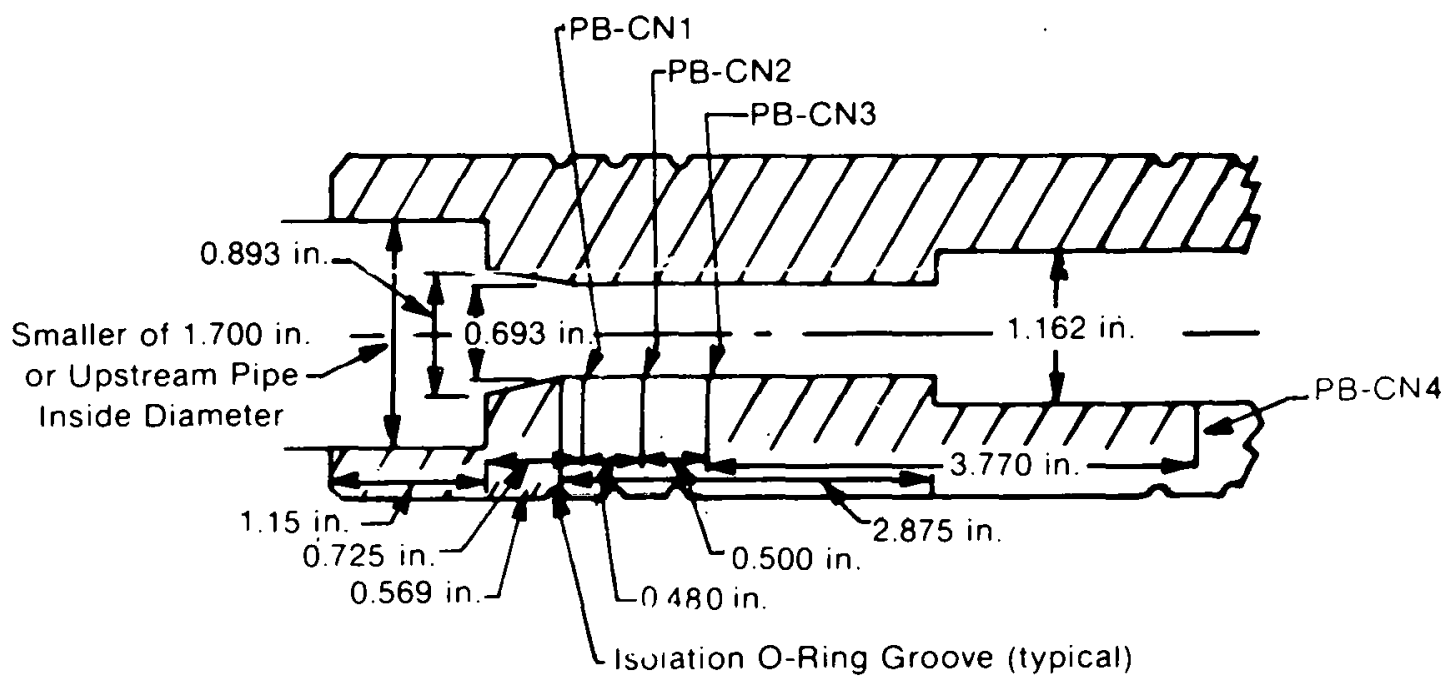

INEL-A-2717

Fig. 2 Elongated throàt nozzle.

Semiscale Mod-1 tests. The elongated throat nozzle has a 2.875 -in. long constant area throat section followed by a step increase in cross-sectional flow area. The pressure taps in the elongated throat nozzle were located geometrically similar to those in the Henry nozzle so that comparison of pressure histories could be made. Pressure taps designated PB-CN1, $\mathrm{PB}-\mathrm{CN} 2$, and PB-CN3 were located in the constant area throat section, and the pressure tap designated $\mathrm{PB}-\mathrm{CN} 4$ was located in the expanded section downstream of the constant area throat section.

The elongated throat nozzle was geometrically scaled from the LOFT nozzle based on length-to-diameter scaling criteria ${ }^{[a]}$. With this design, thermodynamic equilibrium occurs whereas in the Henry noz.7le, thermodynamic nonequlibrium will exist.

The system in which the two nozzle configurations were used is the Semiscale Mod-1 experimental facility. The system, shown in Figure 3, is a high pressure system consisting of a pressure vessel with simulated reactor internals (downcomer, lower plenum, core region, and upper plenum); an intact loop with rupture diaphragm assemblies, simulated steam generator, and simulated pump; a pressure suppression system with supprcssion tank and header; and simulated emergency core coolant (ECC) injection system with accumulators and injection pumps. The system water volume is approximately $7.440 \mathrm{ft}^{3}$. Detailed descriptions of the system components, including volumes and flow resistances, and of the measurement and data acquisition systems are contained in Reference 3.

[a] These scaling criteria were chosen for the elongated nozzle so as to maintain the nozzle geometrically similar to the LOFT nozzle, and resulted in break flow rates typical of expected LOFT flow rates for the majority of blowdown. The flow rate comparison will be utilized by the LOFT Program in the specification of future tests. 


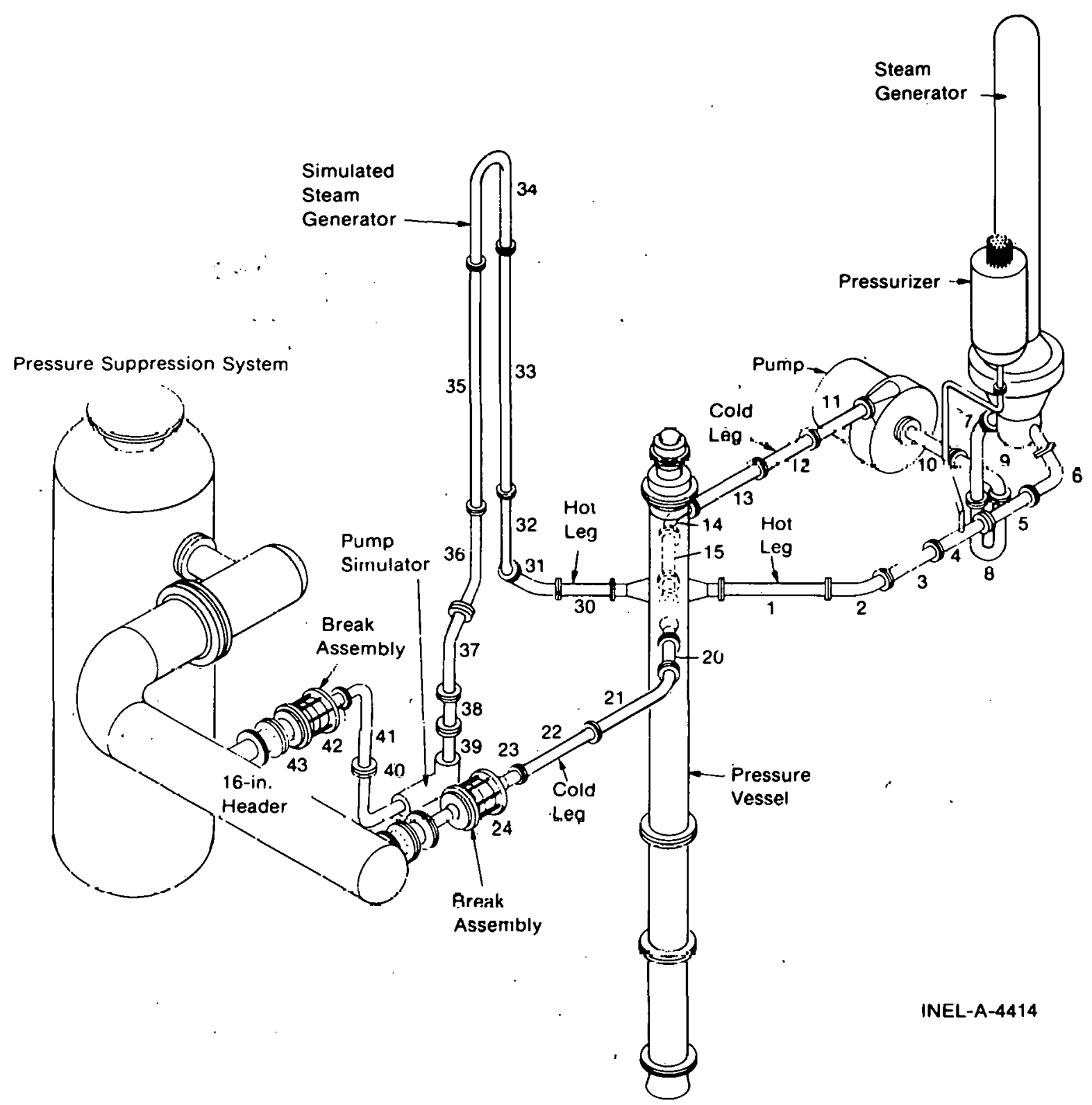

Fig. 3 Semiscale Mod-1 sy stem configuration.

The broken loop accommodates two break nozzles of the same configuration and two rupture assemblies which achieve the spccified double-ended offset shear break. The inserted nozzles are the only components changed between tests.

The core in the Semiscale Mod-1 system consists of 40 electrically heated rods having characteristics lypical of PWR fucl rod diameter and axial power peaking. The measurements taken in the core include rod temperature, fluid temperature, inlet flow rate, and inlet density. 
Measurements taken in the Semiscale system other than in the core include volumetric flow rates, fluid temperatures, pressure drops, pressures, and fluid densities. The expected error in each type of measurement is identified in Reference 3.

The system, in the first case with the Henry nozzle installed and in the second case with the elongated throat nozzle, was brought to equilibrium at a system pressure of $2252 \mathrm{psig}$ and a core flow rate of $147 \mathrm{gpm}$. Once equilibrium was reached throughout the system, the test was initiated by breaking the rupture discs in both the inlet and outlet sides of the broken loop. 


\section{EVALUATION OF THE BREAK NOZZLE CONFIGURATION EFFECT ON THE SYSTEM}

Previous work in the Semiscale Mod-1 experimental program has shown that the flow rates at the break nozzles have major influence on the response of the system. Since the break nozzle configuration may influence the break flow rate, an analysis was performed to evaluate the effect of break nozzle configuration on the break flow rate and the rest of the system.

In addition, separate effects studies on the influence of nozzle geometry conducted by Sozzi and Sutherland [4] have shown that nozzle geometry can influence the fluid conditions and thereby the nuzzle fluw rates.

The results presented herein provide an opportunity to evaluate the effect of nozzle geometry in the context of the Semiscalc system and to determine whether differences in the fluid conditions at the break significantly influence the system response.

This section of the report presents the results of the comparison of the Henry nozzle and the elongated throat nozzle. The first section contains an evaluation of the influence of break nozzle configuration on the break fluid conditions and break flow rates. The secund section presents the core hydraulic and thermal response due to the break nozzle configuration differences, and presents an apparent correlation between the core flow reversal, early in subcooled blowdown, and the core thermal response.

\section{EVALUATION OF THE BREAK BEHAVIOR}

An evaluation of the effect of the break nozzle geometry on fluid behavior at the break has been made by a comparison of blowdown data from tests utilizing the Henry nozzle and the elongated throat nozzle. A comparison of the break flow rate for the tests which differed only in break nozzle configuration is presented in Figure 4. The results presented in this figure show that the break flow was lower during subcooled blowdown $(0$ to $2.4 \mathrm{sec})$ in the elongated throat nozzle than was observed in the Henry nozzle, but the difference in break flow between the two nozzles is smaller during the saturated portion of blowdown (after $3.6 \mathrm{sec}$ ). The time that transition from subcooled to saturated blowdown occurred was delayed from about $2.5 \mathrm{sec}$ for the test with the Henry nozzle to about $3 \mathrm{sec}$ when the elongated throat nozzle was utilized. Transition is indicated in Figure 4 when the mass flow rate drops suddenly. Figure 5 compares the time at which saturated liquid reached the break and shows the delay of about $0.5 \mathrm{sec}$ for the case using the elongated throat nozzle. Since the higher temperature liquid that reached the break nozzles originated in the core, the differences in the time that the saturation temperature was reached at the break indicate that a difference exists in core response due to the difference in break nozzle configuration. The influence of the lower subcooled break flow on the response of the core is discussed subsequently. 


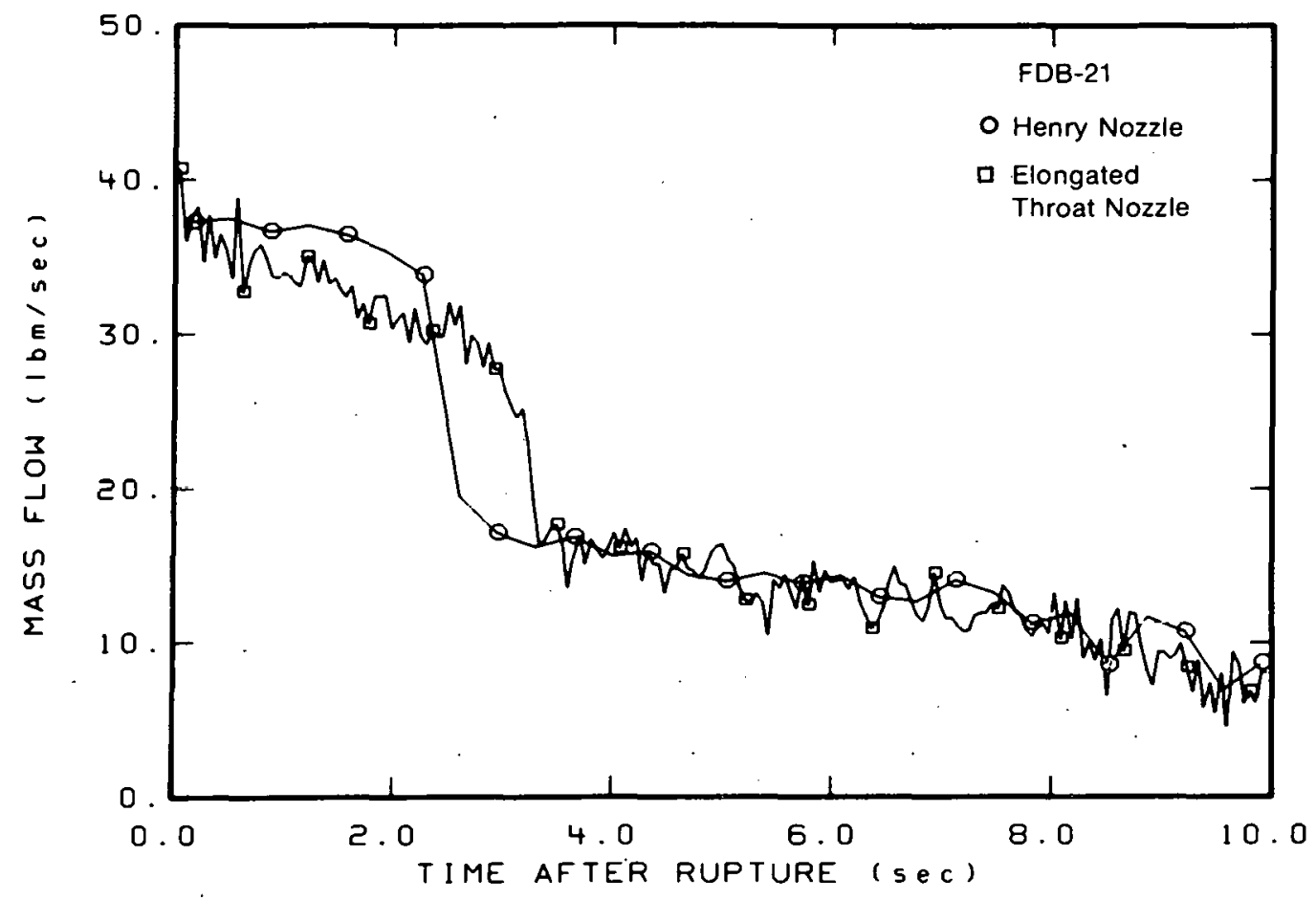

Fig. 4 Break flow rate during early blowdown.

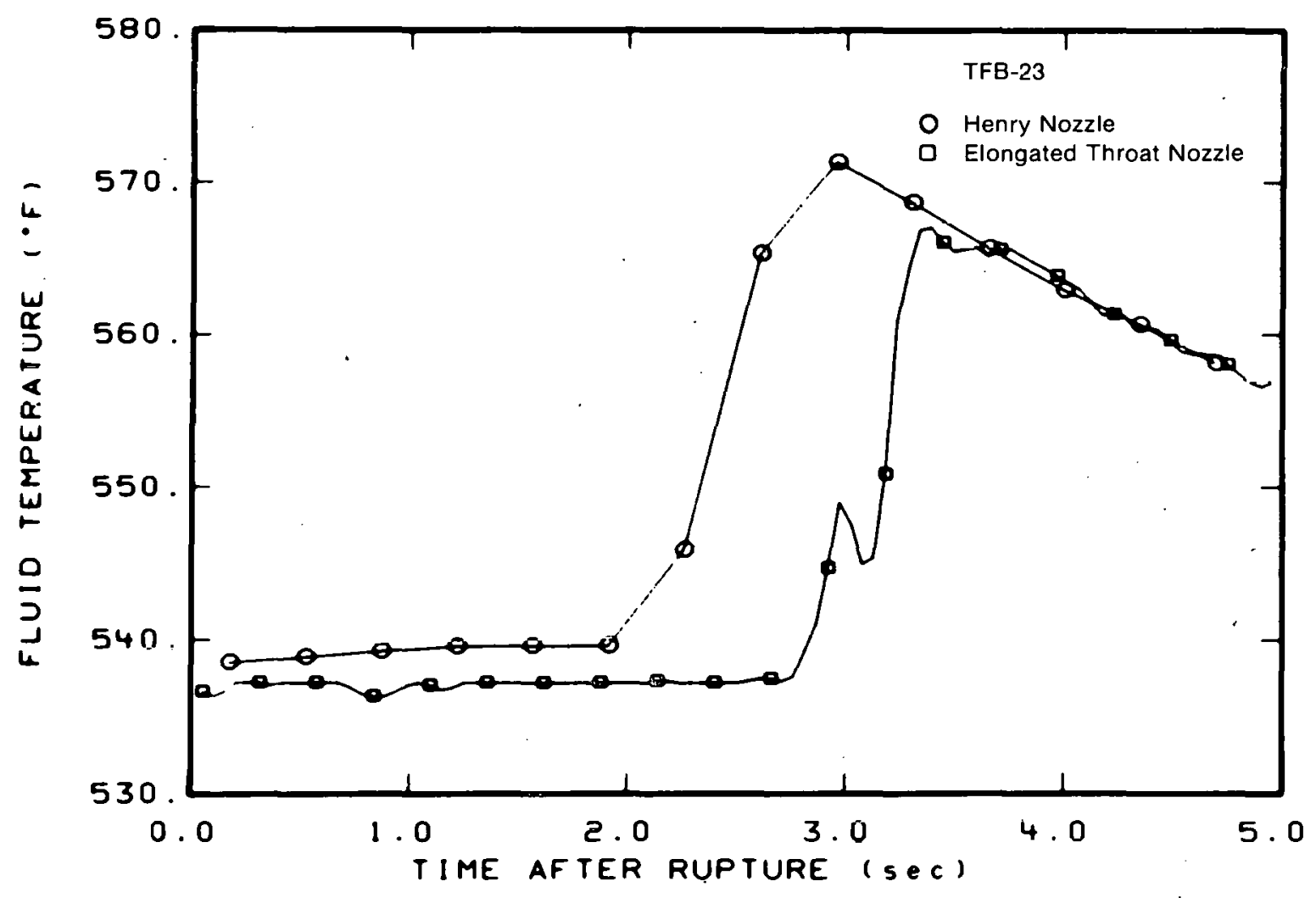

Fig. 5 Fluid temperature upstream of tho brcak nozzle (TFB-23). 
Insight into the reasons for break flow differences can be gained by studying the pressure measured in and around the break nozzles. System depressurization upstream of the nozzles was essentially the same for the two tests, as shown in Figure 6. Figure 7 illustrates the difference in pressure response at the minimum area of the Henry nozzle and at the beginning of the throat of the elongated throat nozzle. The pressure at the nozzle throat (PB-CN1) followed the saturation pressure in the elongated throat nozzle whereas in the Henry nozzle the pressure at the minimum area (PB-CN1) dropped significantly below the saturation pressure. This decrease in throat pressure below saturation conditions, which is a thermodynamic nonequilibrium state, indicates that the fluid in the Henry nozzle was accelerating to a higher velocity than that in the elongated throat nozzle, which contributed to the higher subcooled break flow for the Henry nozzle as illustrated in Figure 4.

Pressure measurements within the elongated throat nozzle were evaluated to determine the nozzle fluid conditions. Figure 8 shows the pressure history upstream, downstream, and within the elongated throat nozzle. The upstream pressure (PB-23) reflects the system depressurization. The downstream pressile is denoted by PB-24 and was measured below the nozzle section. The three pressure taps within the constant area throat, designated PB-CN1, PB-CN2, and PB-CN3, are located in the upstream half of the constant area section. The length-to-diameter (L/D) ratio for this nozzle configuration is 4.97 . This value of $L / D$ results in a fluid residence time in the nozzle throat such that nucleation may result in the existence of thermodynamic equilibrium within the nozzle ${ }^{[5]}$. Figure 8 shows that the three nozzle throat pressures were essentially the same, indicating equilibrium was

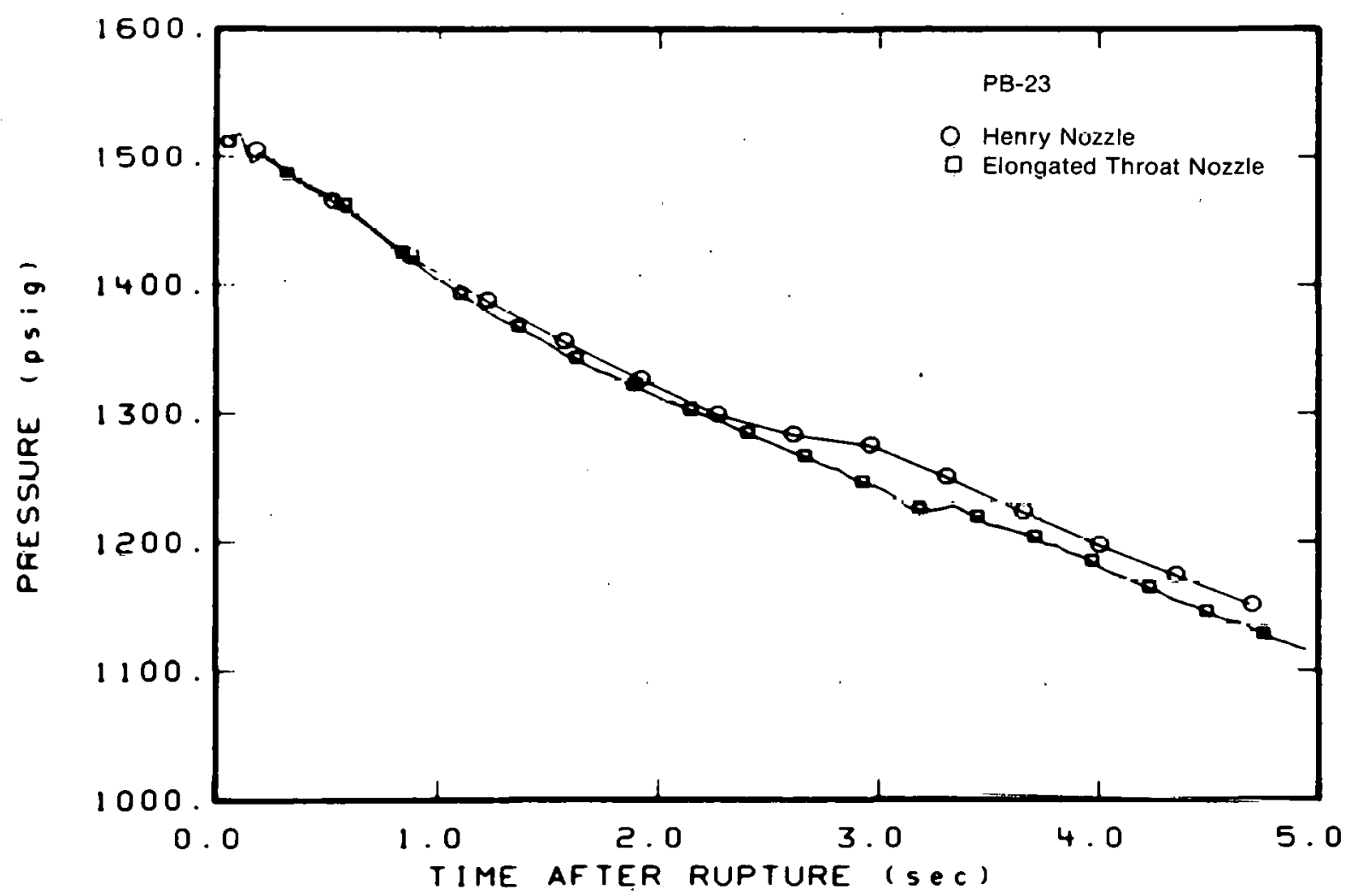

Fig. 6 Pressure upstream of the break nozzle (PB-23). 


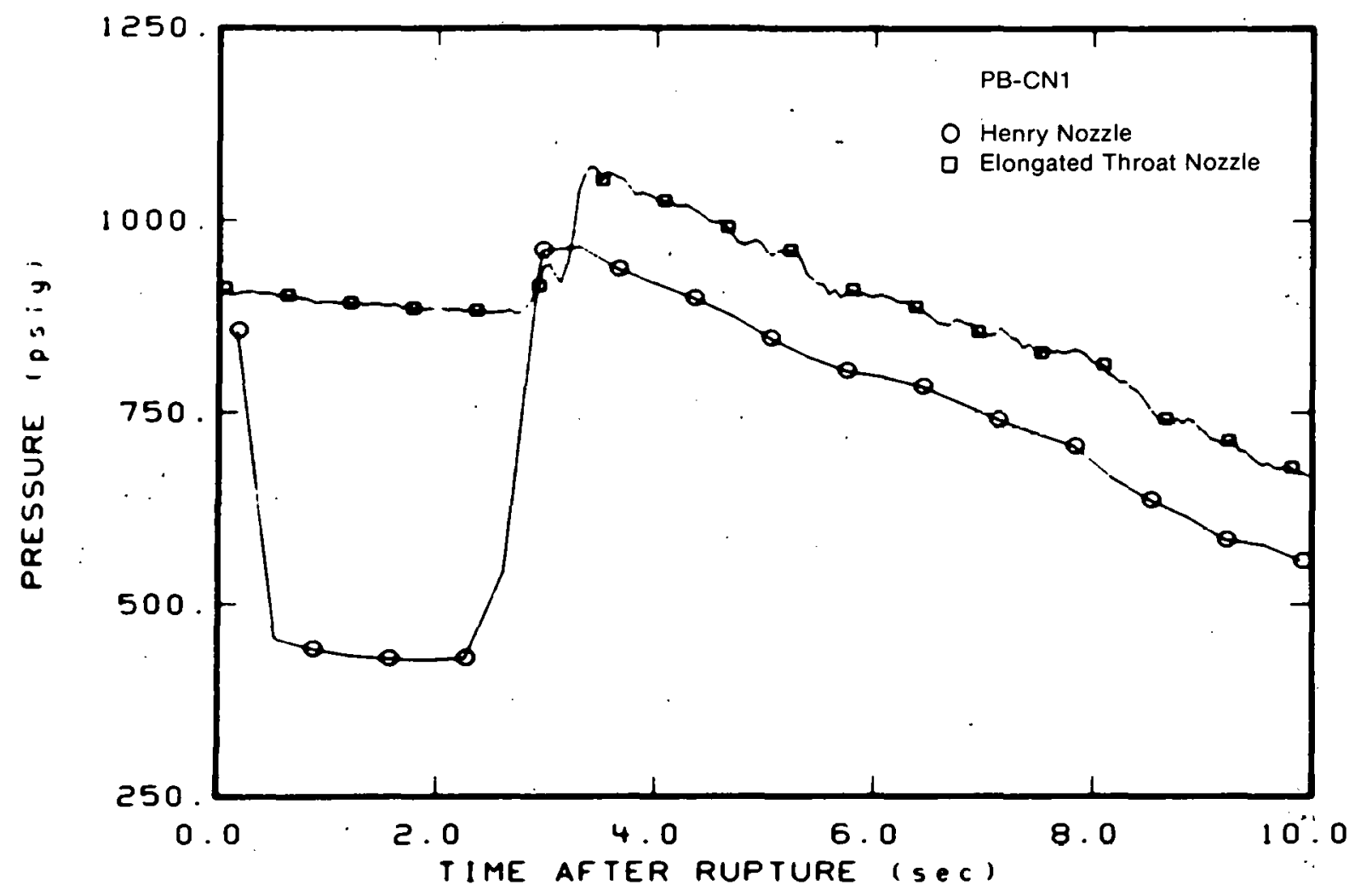

Fig. 7 Throat pressure in the break nozzle (PB-CN1).

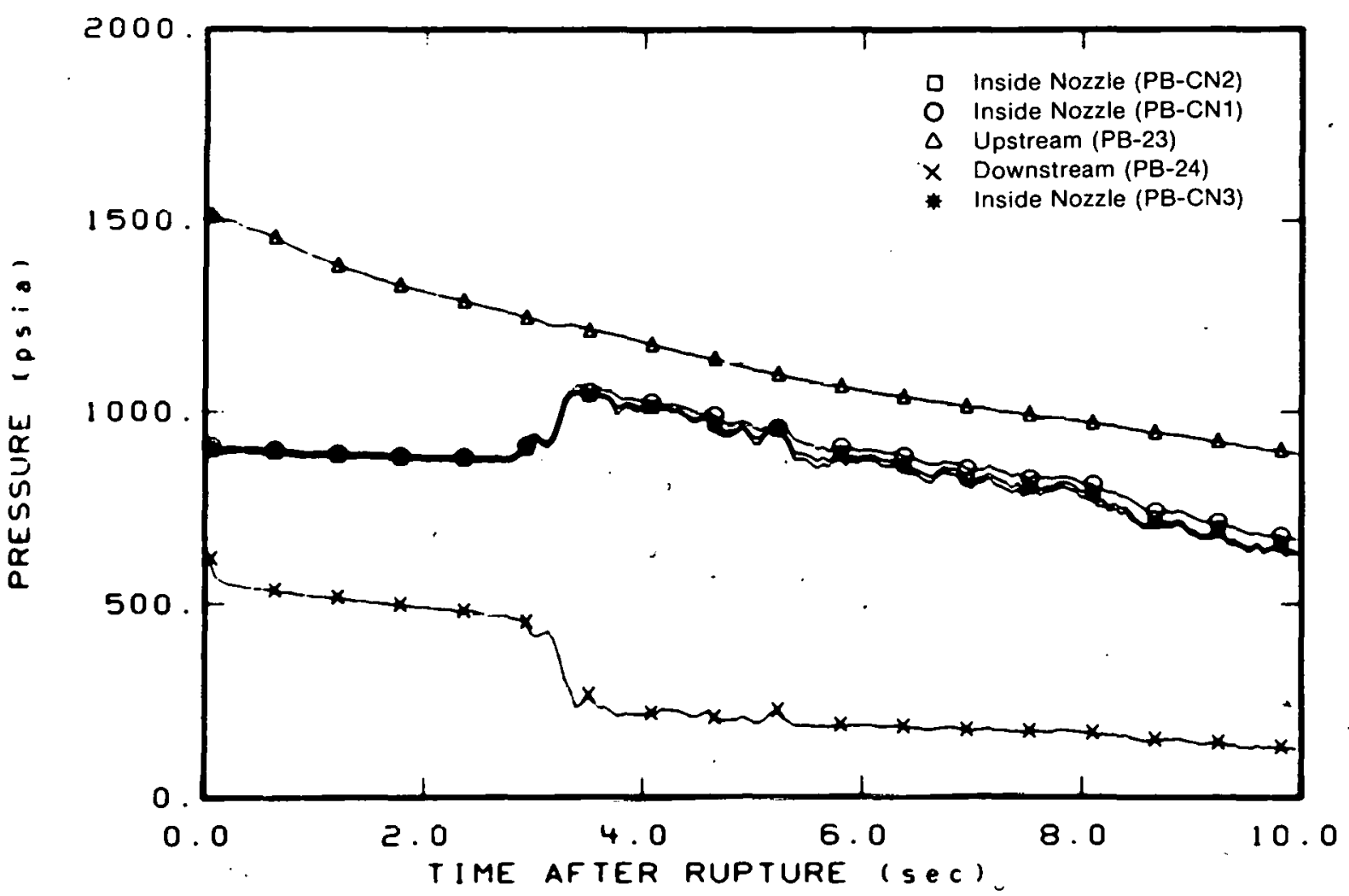

Fig. 8 Pressure history in the elongated throat nozzle. 
maintained in the throat at least past the furthest downstream throat tap (PB-CN3). Since choking cannot occur in a convergent section, the choking plane appears to exist downstream of the PB-CN3 pressure tap, probably at the throat exit. In the Henry nozzle the existence of superheated liquid at the nozzle throat would be expected to cause choking at the minimum area and flashing in the divergent section. The differences in the fluid thermodynamic state observed within the two nozzles appear to have caused the break flow differences during the subcooled blowdown. Upon initiation of saturated conditions at the break the flows became similar due to the existence of similar saturated conditions upstream of and within the nozzles.

\section{CORE RESPONSE EARLY IN BLOWDOWN}

The evaluation of test data obtained with the Henry nozzle and the elongated throat nozzle has been made to determine whether the system response was significantly influenced by break nozzle configuration. This evaluation indicated that the system response was not significantly different except for the core thermal-hydraulic behavior. Following is a discussion of the differences in response observed within the core. Data from other tests and an analysis using the RELAP4 code are used to aid in understanding the observed core behavior.

The lower break flow rate observed during early blowdown when the elongated throat nozzle was used resulted in a corc flow reversal which was also lower. Figure 9 shows the volumetric flow at the core inlet for the tests using each of the break nozzle configurations. The larger break flow through the Henry nozzle resulted in the larger reversed core flow that is seen in Figure 9. This figure also illustrates the influence on the core flow of the 0.5-sec difference in transition time from subcooled to saturated blowdown. This difference is seen by comparing the times at which the reversed core inlet flow suddenly dropped off.

The difference in core flow reversal due to the two different break configurations substantially affected the core thermal response, as shown in Figures 10, 11, and 12 which illustrate the rod temperature behavior within the high power zone of the core (20-, 25-, and 28-in. core elevations). The figures show that when the initial core flow reversal was large (as was the case with the Henry nozzle) the departure from nucleate boiling (DNB), which is accompanied by a temperature rise early in the tests, was delayed. With the reduced core flow reversal, due to the elongated throat nozzle conflguration, less heat removal from the core was available and more of the rod locations exhibited earlier DNB behavior. As a result, the average maximum core temperature was higher when the elongated throat nozzle was used. Table I presents the maximum cladding tempcrature for each of the thermocouples recorded.

The trend observed between the magnitude of the initial core flow reversal and the core DNB behavior is supported by the results of other Semiscale Mod-1 tests, especially Test S-05-5[6]. Test S-05-5 was part of the alternate ECC test series and had an upper plenum vent which opened early in the test resulting in relatively small initial core flow 


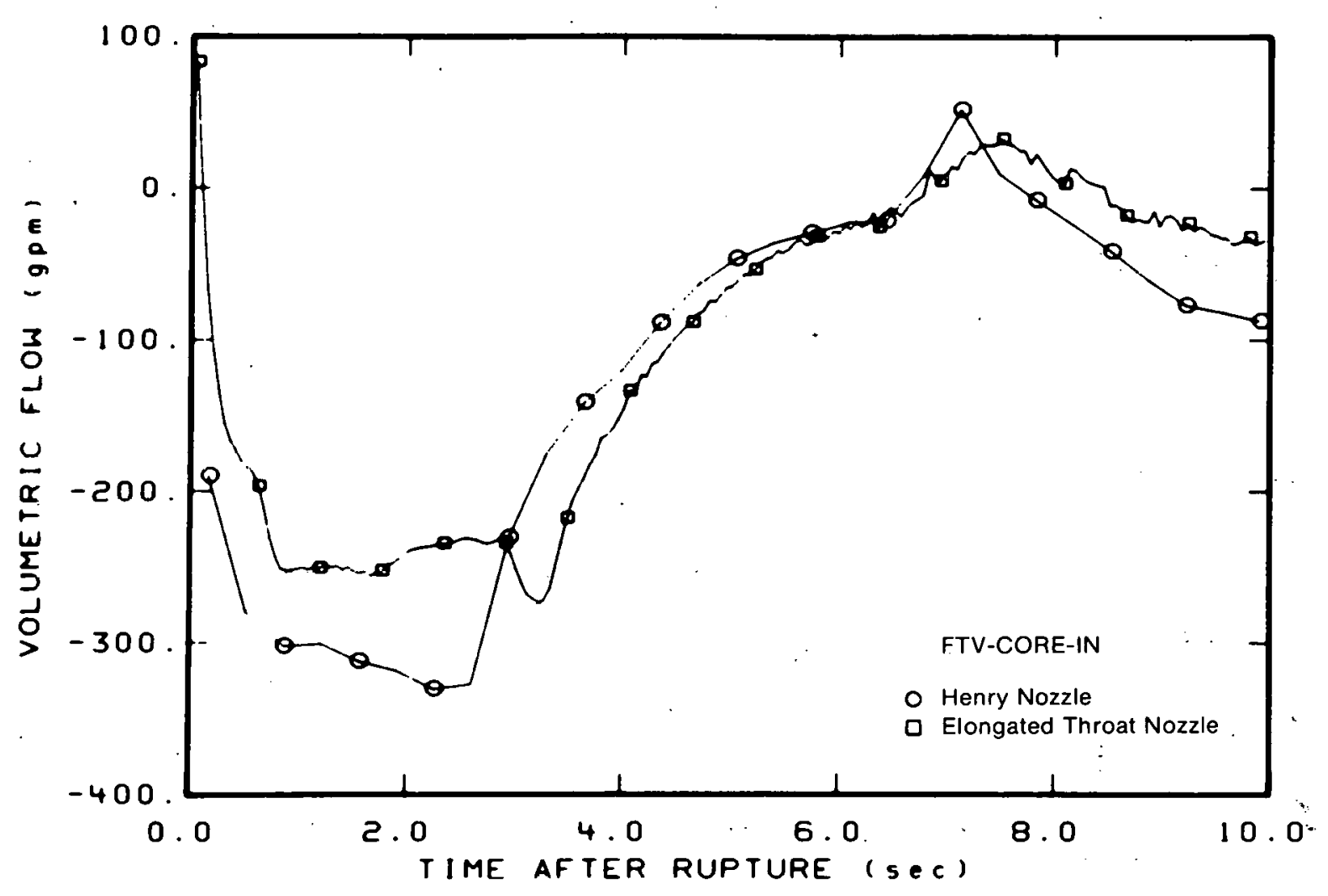

Fig. 9 Core inlet flow rate during early blowdown (FTV-CORE-IN).

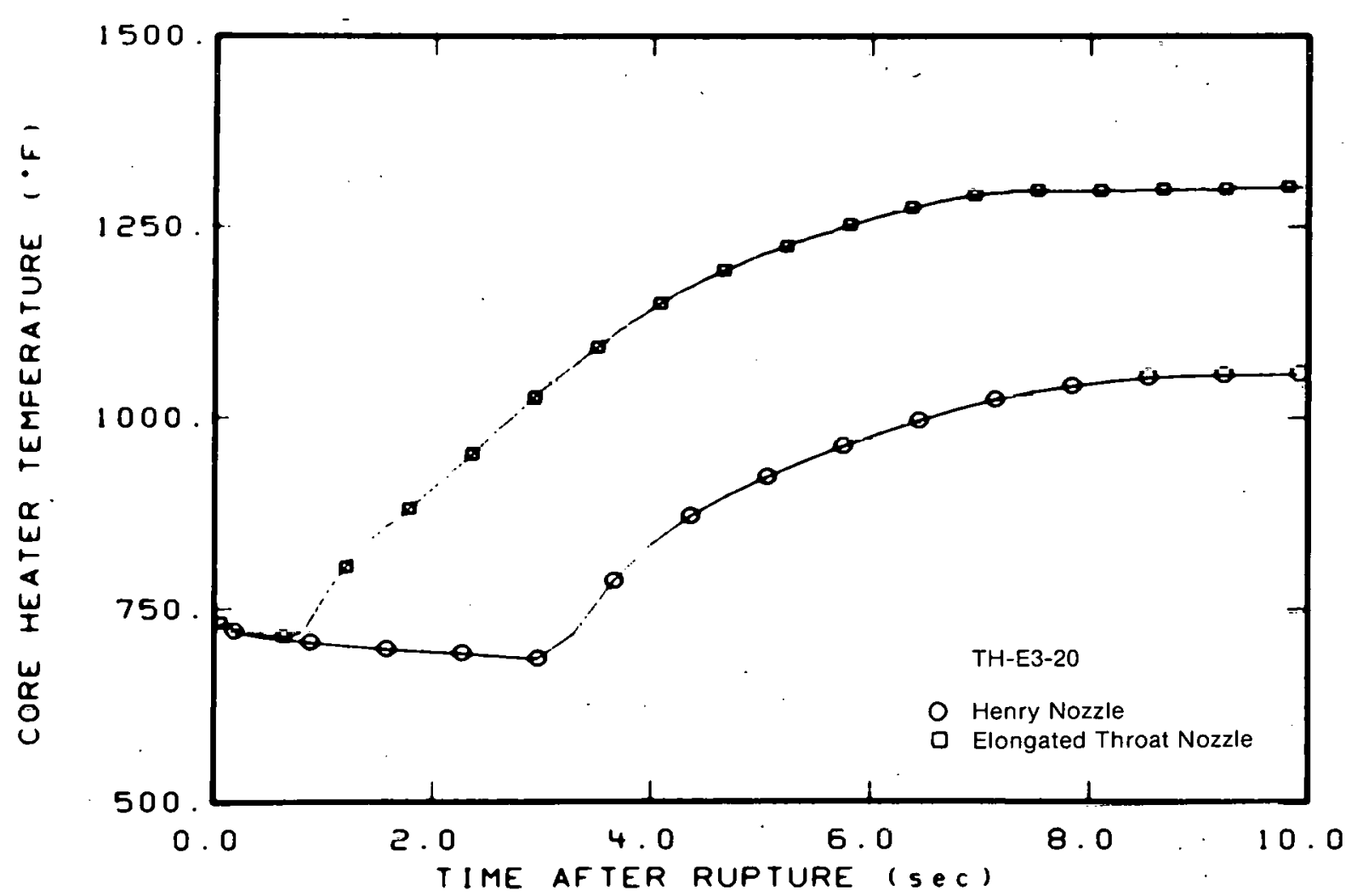

Fig. 10 Heater rod response at location TH-E5-20 (20-in. elevation). 


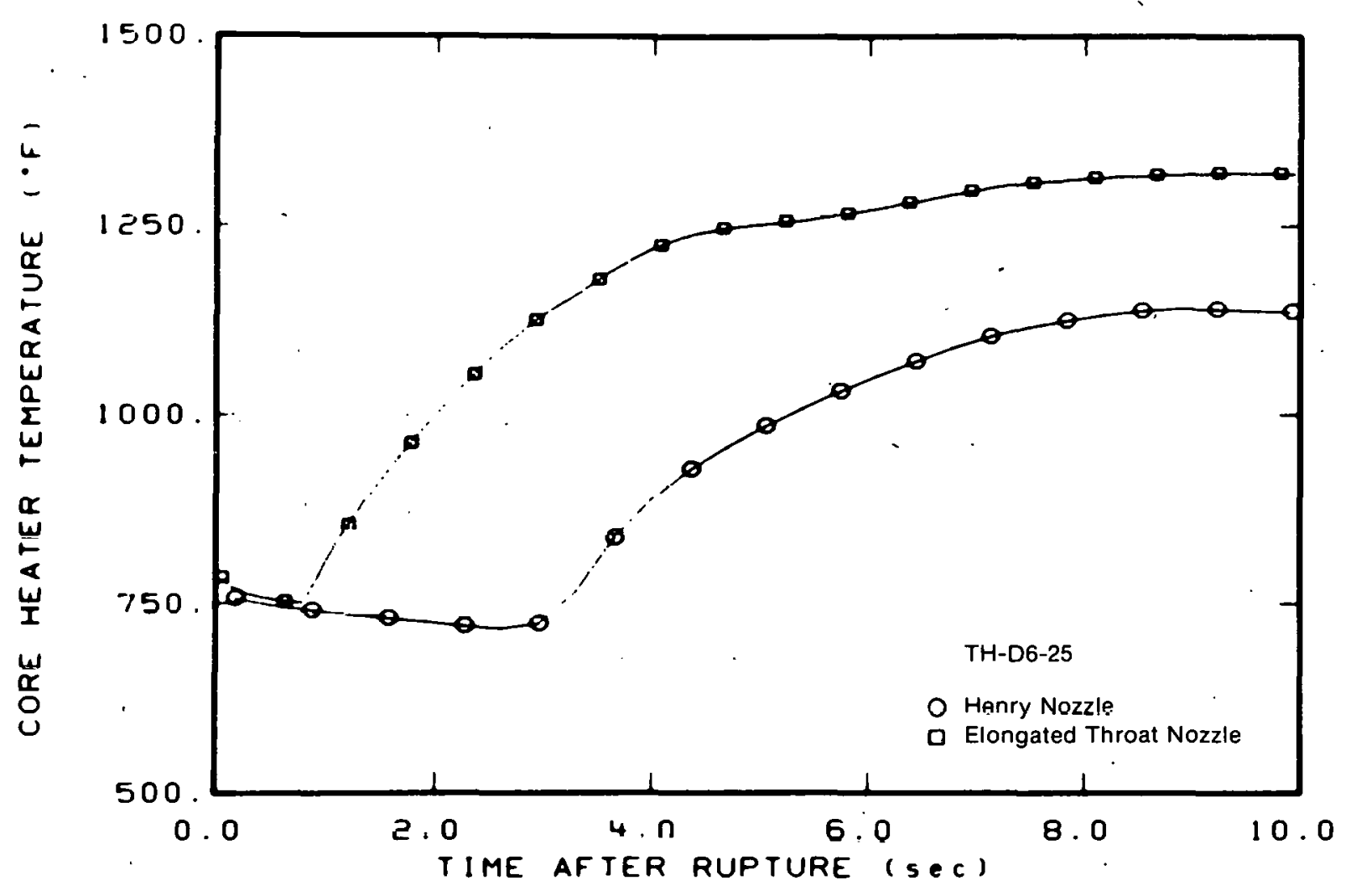

Fig. 11 Heater rod response at location TH-D6-25 (25-in. elevation).

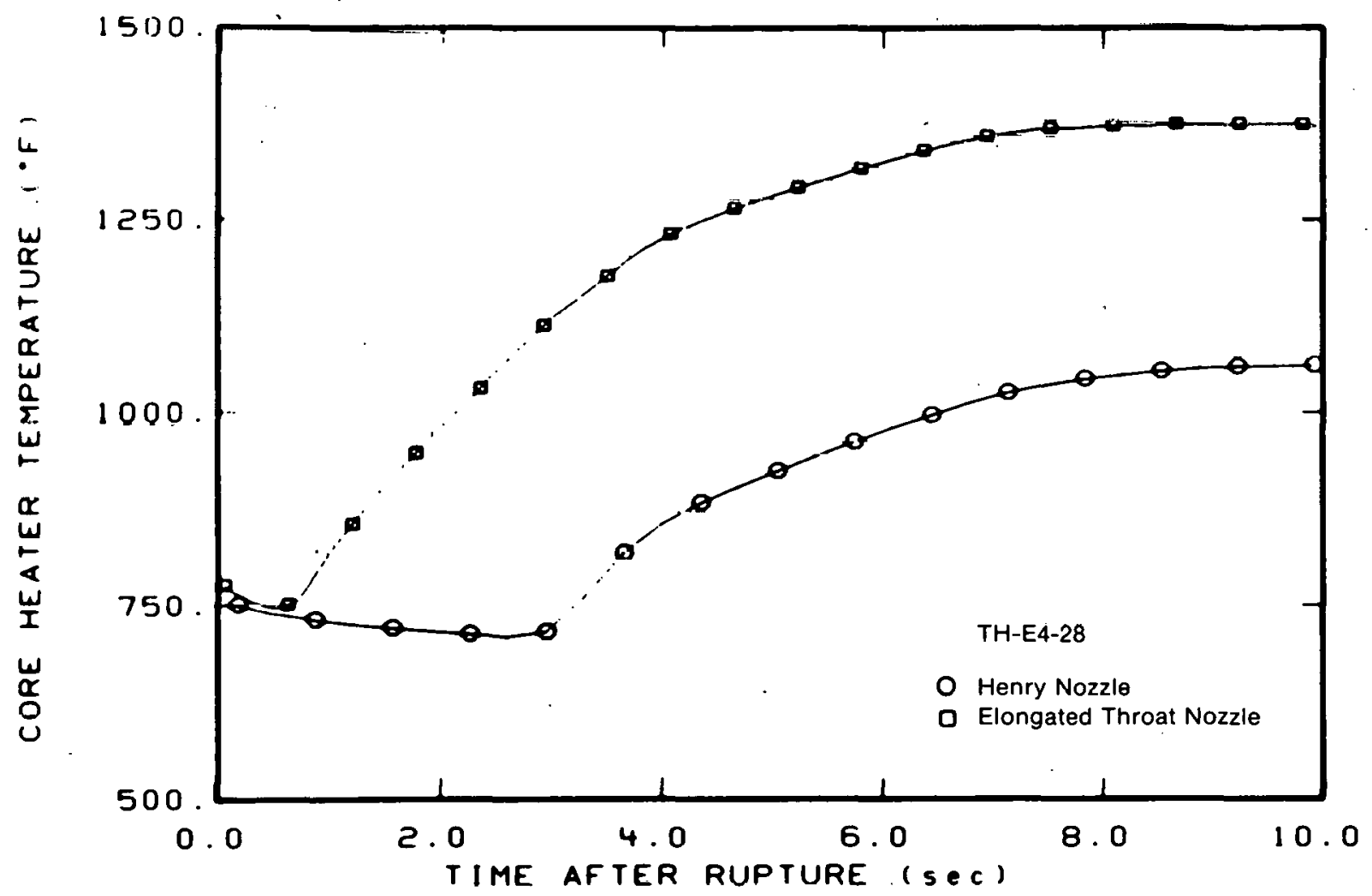

Fig. 12 Heater rod response at location TH-E4-28 (28-in. elevation). 
COMPARISON OF MAXIMUM ROD CLADDING TEMPERATURES FOR THE HENRY NOZZLE AND THE ELONGATED THROAT NOZZLE

\begin{tabular}{|c|c|c|c|c|c|}
\hline \multicolumn{3}{|c|}{$\begin{array}{l}\text { Maximum Cladding } \\
\text { Temperature }\left({ }^{\circ} \mathrm{F}\right)\end{array}$} & \multicolumn{3}{|c|}{$\begin{array}{l}\text { Maximum Cladding } \\
\left.\text { Temperature ( }{ }^{\circ} \mathrm{F}\right)\end{array}$} \\
\hline Thermocouple & $\begin{array}{l}\text { Henry } \\
\text { Nozzle }\end{array}$ & $\begin{array}{c}\text { Elongated } \\
\text { Throat } \\
\text { Nozzle } \\
\end{array}$ & Thermocouple & $\begin{array}{l}\text { Henry } \\
\text { Nozzle }\end{array}$ & $\begin{array}{c}\text { Elongated } \\
\text { Throat } \\
\text { Nozzle } \\
\end{array}$ \\
\hline $\begin{array}{l}\text { TH-E3-05 }[\mathrm{a}] \\
\text { TH-C7-07 } \\
\text { TH-F2-07 [a] } \\
\text { TH-A4-09 }[\mathrm{a}] \\
\text { TH-E4-09 } \\
\text { TH-E6-09 } \\
\text { TH-G3-13 } \\
\text { TH-D2-14 } \\
\text { TH-D4-14 } \\
\text { TH-D6-14 [a] } \\
\text { TH-E8-14 } \\
\text { TH-F4-14 } \\
\text { TH-G5-14 } \\
\text { TH-D7-20 [a] } \\
\text { TH-E3-20 } \\
\text { TH-F5-20 }[\mathrm{a}] \\
\text { TH-D1-21 } \\
\text { TH-F2-22 } \\
\text { TH-E3-24 } \\
\text { TH-G5-24 } \\
\text { TH-D6-25 } \\
\text { TH-F2-25 } \\
\text { TH-C4-26 } \\
\text { TH-F5-26 }[\mathrm{a}] \\
\text { TH-B5-28 } \\
\text { TH-C5-28 } \\
\text { TH-E4-28 } \\
\text { TH-E6-28 } \\
\text { TH-F4-28 }[\mathrm{a}] \\
\text { TH-A4-29 } \\
\text { TH-A5-29 }[\mathrm{a}] \\
\text { TH-B6-29 } \\
\text { TH-D3-29 } \\
\text { TH-D4-29 }[\mathrm{a}] \\
\text { TH-E8-29 } \\
\text { TH-G4-29 } \\
\text { TH-H5-32 }\end{array}$ & $\begin{array}{l}1280 \\
1063 \\
1138 \\
1459 \\
1255 \\
1221 \\
1308 \\
1267 \\
1226 \\
1220 \\
1266 \\
1289 \\
1247 \\
1223 \\
1232 \\
1232 \\
1332 \\
1476 \\
1427 \\
1192 \\
1185 \\
1335 \\
1282 \\
1244\end{array}$ & $\begin{array}{l}1297 \\
1301 \\
1131 \\
148 / \\
1471 \\
1213 \\
1498 \\
1342 \\
1220 \\
1254 \\
1083 \\
1503 \\
1294 \\
1374 \\
1163 \\
1033 \\
1501 \\
1514 \\
1527 \\
1018 \\
1112 \\
1481 \\
1091 \\
1294\end{array}$ & $\begin{array}{l}\text { TH-B3-33 [a] } \\
\text { TH-B5-33[a] } \\
\text { TH-E1-33 [a] } \\
\text { TH-E2-33 } \\
\text { TH-E5-33 } \\
\text { TH-G4-33 } \\
\text { TH-E6-37 } \\
\text { TH-C2-38 } \\
\text { TH-D3-39 [a] } \\
\text { TH-A5-44 } \\
\text { TH-F4-44 } \\
\text { TH-E7-45 [a] } \\
\text { TH-E8-45 } \\
\text { TH-C4-53 } \\
\cdot \text { TH-F5-54 } \\
\text { TH-E4-55 [a] } \\
\text { TH-D8-57 } \\
\text { TH-D2-61 }\end{array}$ & $\begin{array}{l}1041 \\
1081 \\
1014 \\
1131 \\
1189 \\
1198 \\
999 \\
785 \\
\\
827 \\
786 \\
805 \\
922 \\
816 \\
654 \\
637 \\
679 \\
699 \\
634\end{array}$ & $\begin{array}{r}1011 \\
1236 \\
1155 \\
965 \\
905 \\
950 \\
850 \\
892 \\
\\
824 \\
841 \\
755 \\
820 \\
814 \\
652 \\
638 \\
678 \\
667 \\
633\end{array}$ \\
\hline
\end{tabular}

[a] Thermocouple is on a rod not adjacent to an unpowered rod. 
reversal. Figure 13 shows the core inlet flow for Test S-05-5 and the two nozzle configuration tests. As shown, Test S-05-5 has the lowest reversed core flow and in this test 92.6\% of the measured thermocouples exhibited early DNB response. With the elongated throat nozzle, the core exhibited $75 \%$ early DNB whereas with the Henry nozzle $31 \%$ early DNB was experienced. Table II summarizes the times after rupture at which DNB occurred in each of the three tests.

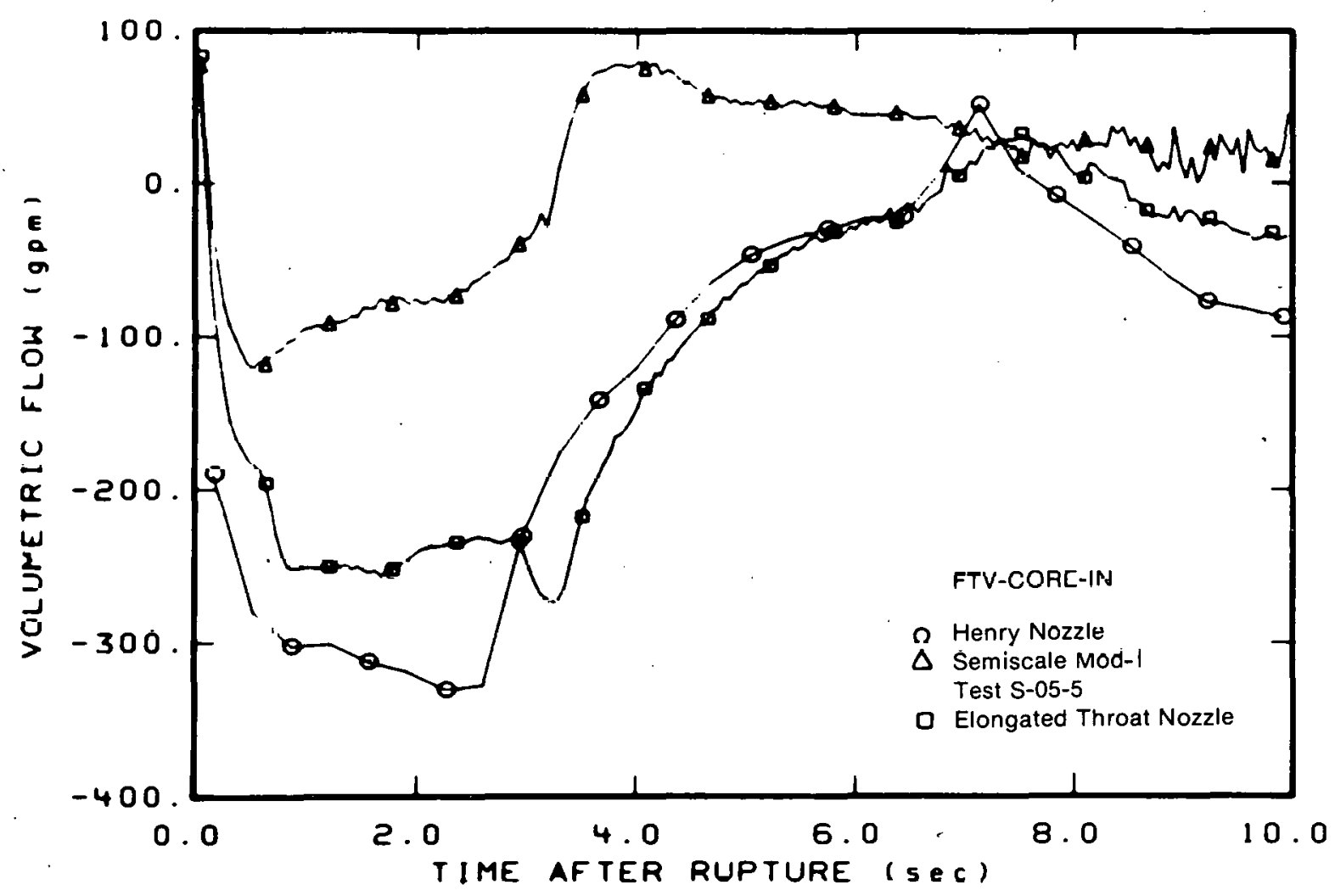

Fig. 13 Core flow during early blowdown. 
TABLE II

TIMES TO DNB FOR THE HENRY NOZZLE, ELONGATED THROAT NOZZLE, AND TEST S-05-5

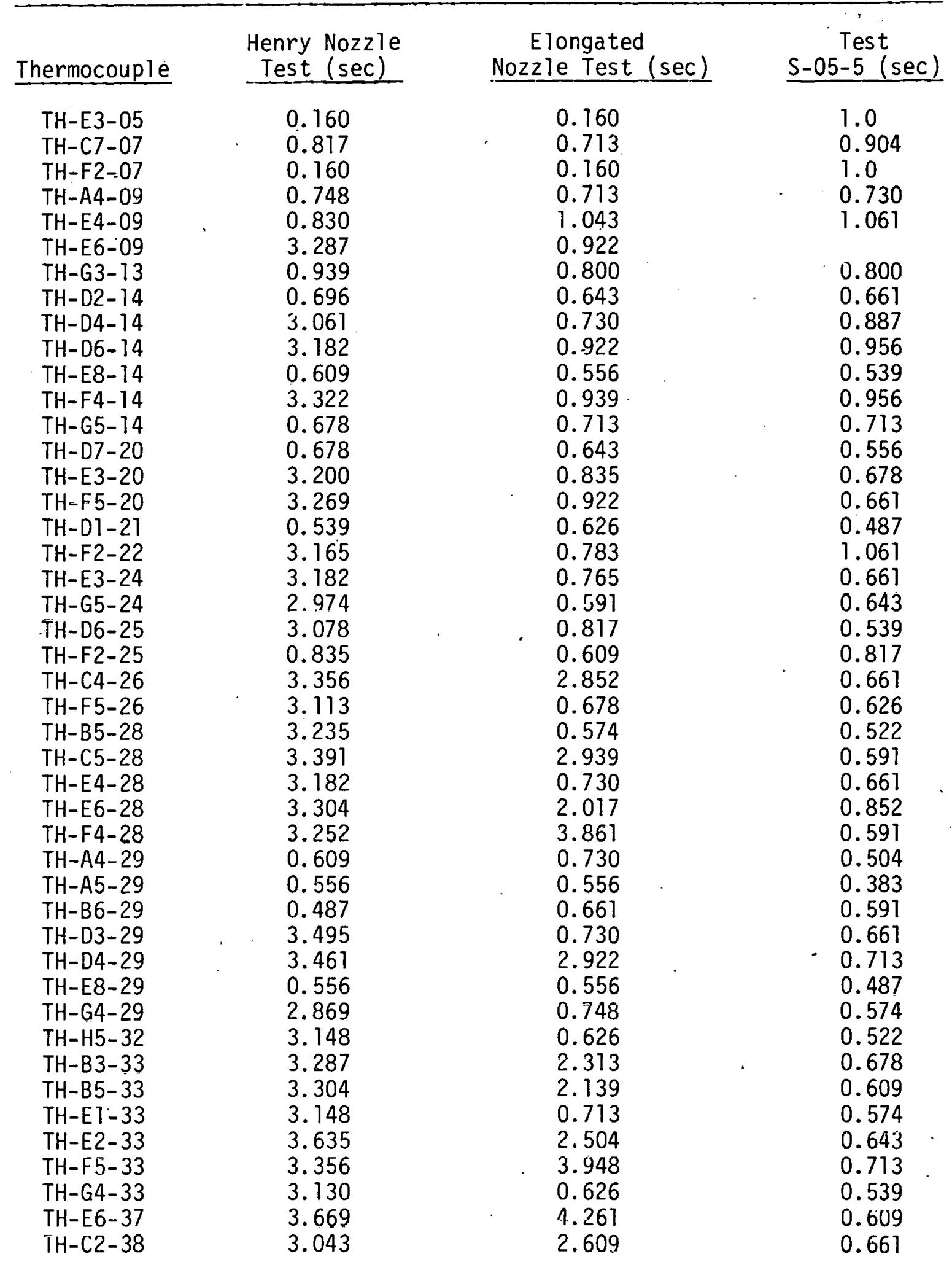


TABLE II (continued).

\begin{tabular}{cccc}
\hline Thermocouple & $\begin{array}{c}\text { Henry Nozzle } \\
\text { Test }(\mathrm{sec})\end{array}$ & $\begin{array}{c}\text { Elongated } \\
\text { Nozzle Test (sec) }\end{array}$ & $\begin{array}{c}\text { Test } \\
\text { S-05-5 (sec) }\end{array}$ \\
\cline { 2 - 4 } TH-G4-38 & 3.269 & & 0.696 \\
TH-D3-39 & 3.548 & 2.539 & 0.678 \\
TH-A5-44 & 3.495 & 0.643 & 0.852 \\
TH-F4-44 & 3.180 & No DNB & 0.696 \\
TH-E7-45 & 3.600 & No DNB & 0.765 \\
TH-E8-45 & 3.440 & No DNB & 3.40 \\
TH-C4-53 & No DNB & No DNB & 3.70 \\
TH-F5-54 & No DNB & No DNB & 3.10 \\
TH-E4-55 & No DNB & 1.861 & 2.85 \\
TH-D8-57 & No DNB & No UNB & No DNB \\
TH-D2-61 & No DNB & No DNB & \\
\hline
\end{tabular}

Additional insight into the core response differences was gained by utilizing the RELAP4 core model ${ }^{[a]}$. The RELAP4 core model was supplied with boundary conditions and initial conditions from the data obtained from the tests using the Henry and elongated throat nozzles. Details of this RELAP4 model are describcd in Appendix A. The results from this analy sis showed a difference in the core fluid conditions for the tests utilizing the Henry and elongated throat nozzles. Figures 14 and 15 show the core qualities at the 13.5-, 25.5-, and 58.5-in. elevations for the tests using the Henry noz.7le and the elongated throat nozzle, respectively. Comparison of the two sets of results shows that the quality increases earlier and at a faster rate at the 13.5- and 25.5-in. elevations for the test utilizing the elongated throat nozzle. This trend toward higher quality indicates that the critical heat flux would be lower for the test utilizing the elongated throat nozzle and would result in the earlier DNB behavior. Figures 16,17 , and 18 compare the core flows at the 0 -, 27-, and 52-in. elevations for the tests which utilized the Henry and elongated throat nozzles. These results show a difference in calculated core flow behavior throughout the core. Similar differences were also noticed in flow rate data at the core inlet from the tests. Since this model was driven by test data rather than by a modeled break nozzle, the results are believed to be a good indication of the actual core response.

[a] Code configuration control number H00006 IB. 


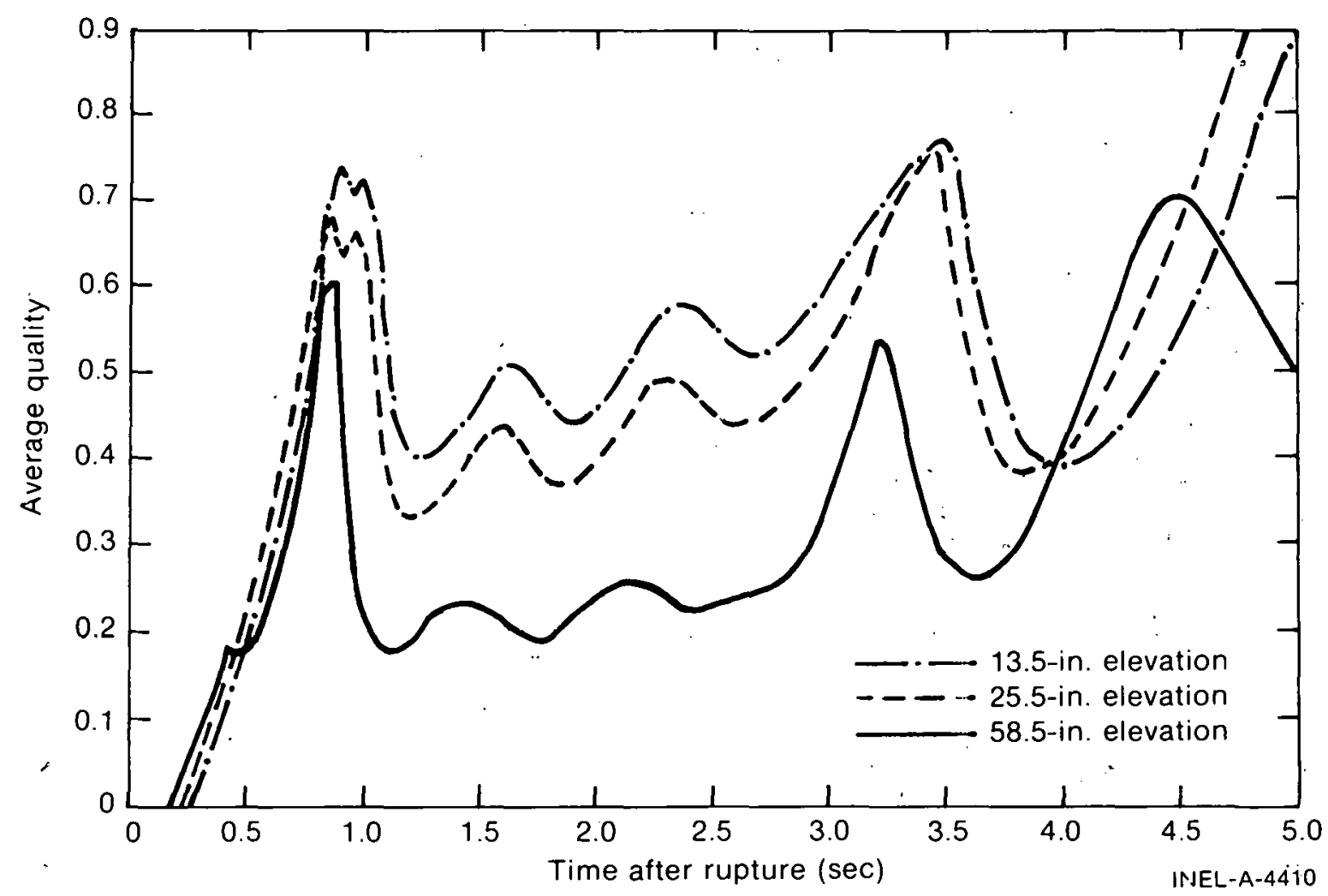

Fig. 14 Fluid quality in the core for the Henry nozzle test.

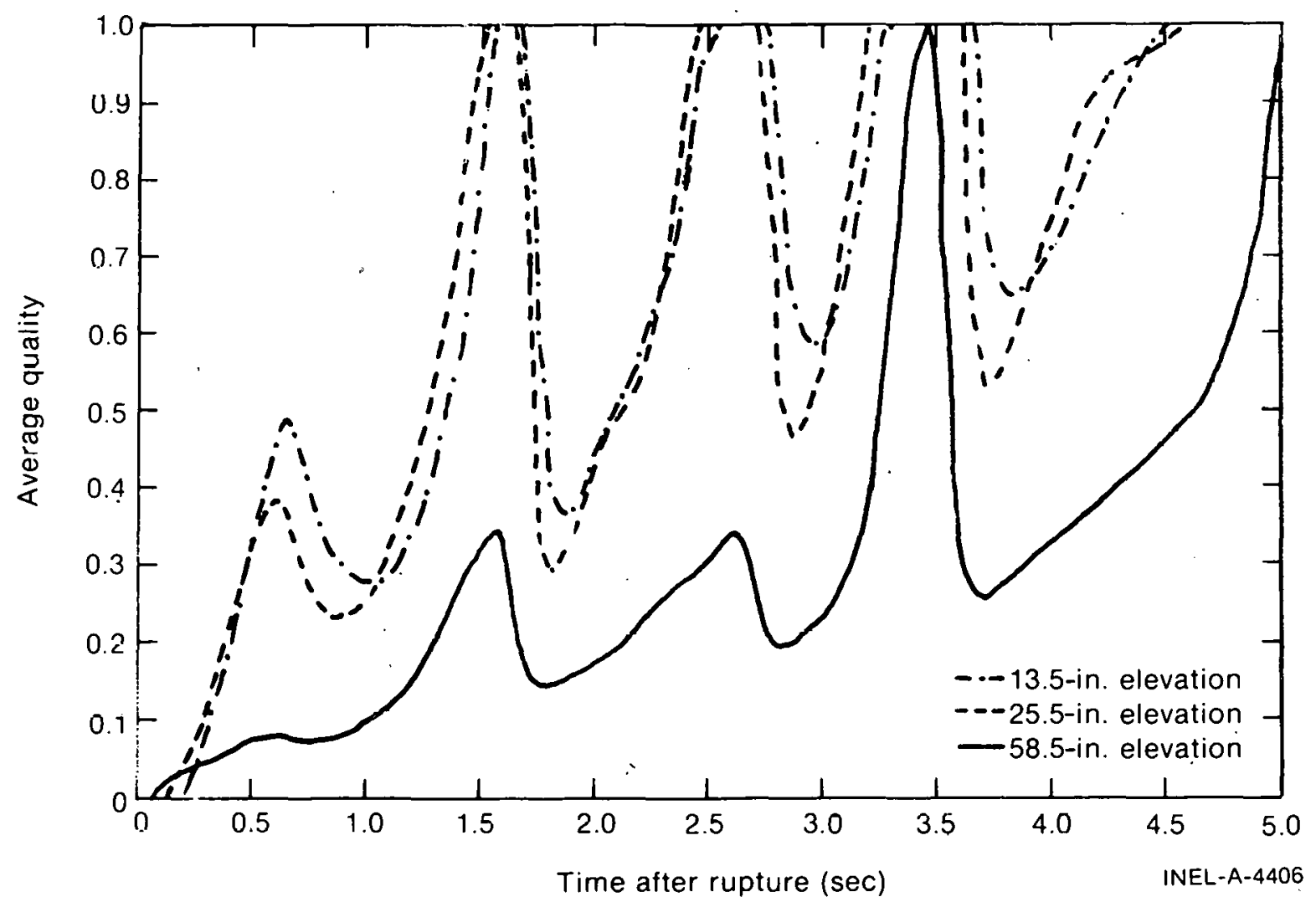

Fig. 15 Fluid quality in the core for the elongated throat nozzle test. 


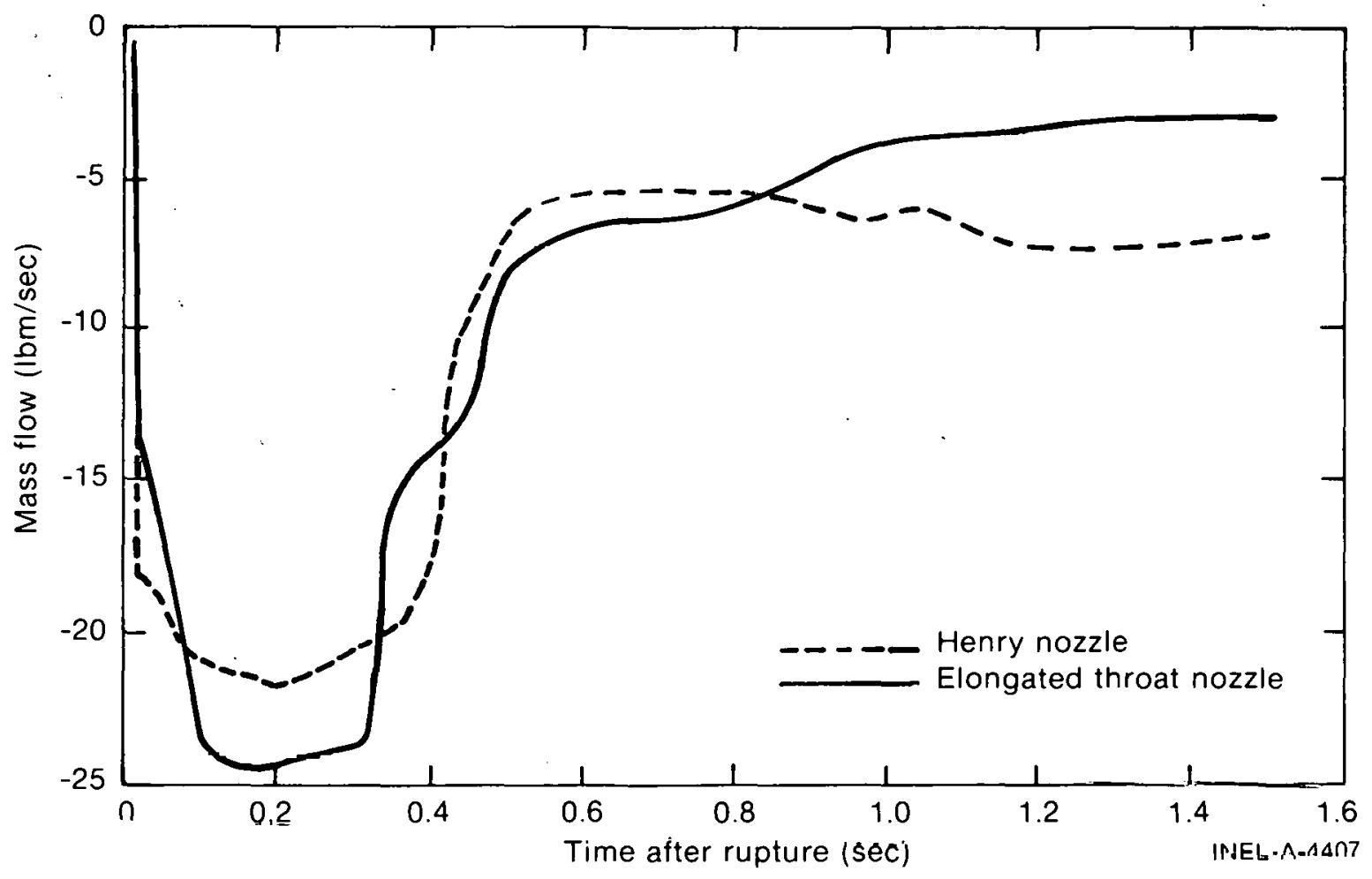

Fig. 16 RELAP4 calculation of mass flow in the core at the inlet.

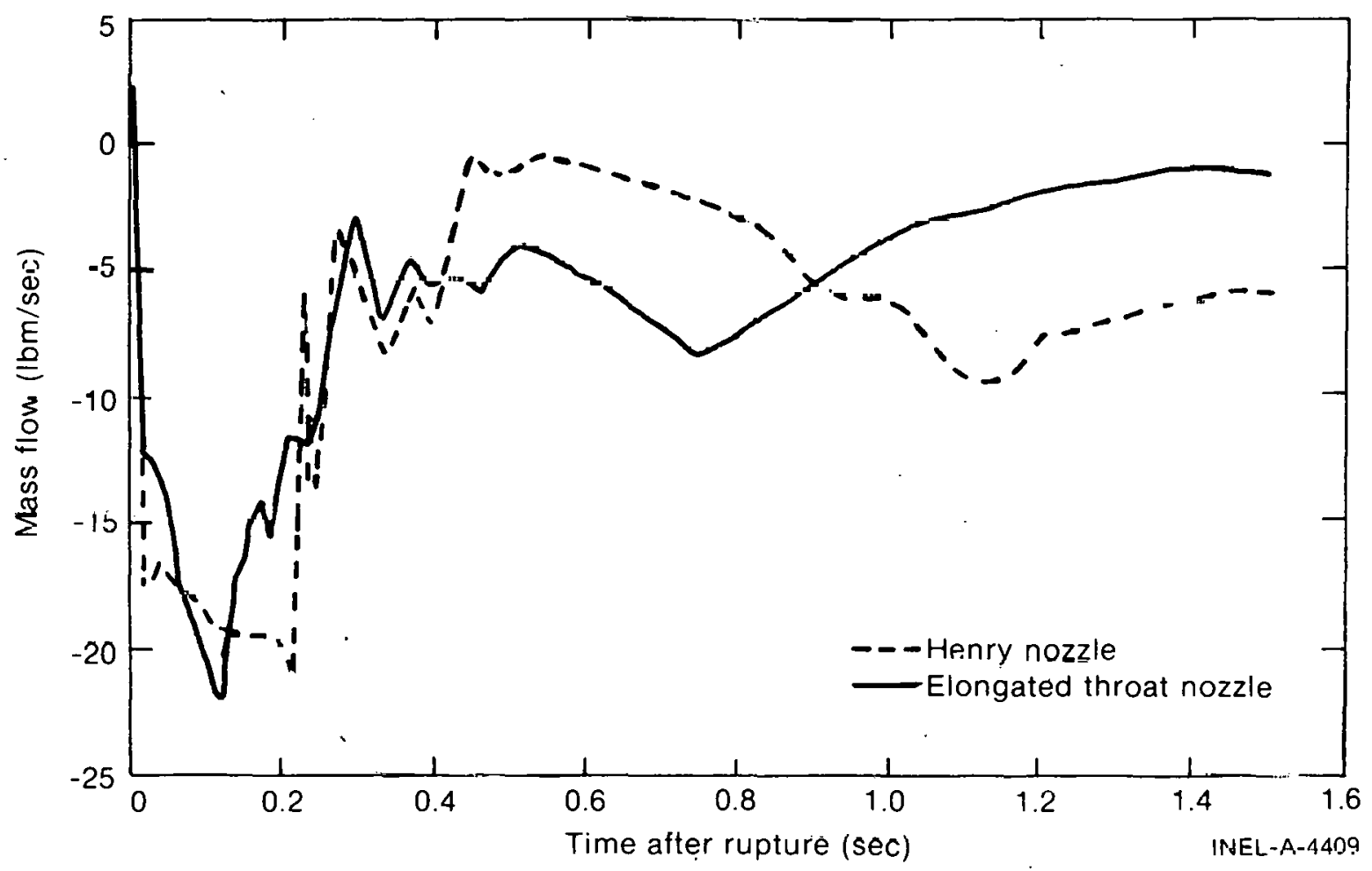

Fig. 17 RELAP4 calculation of mass flow in the core at the 27-in. elevation. 


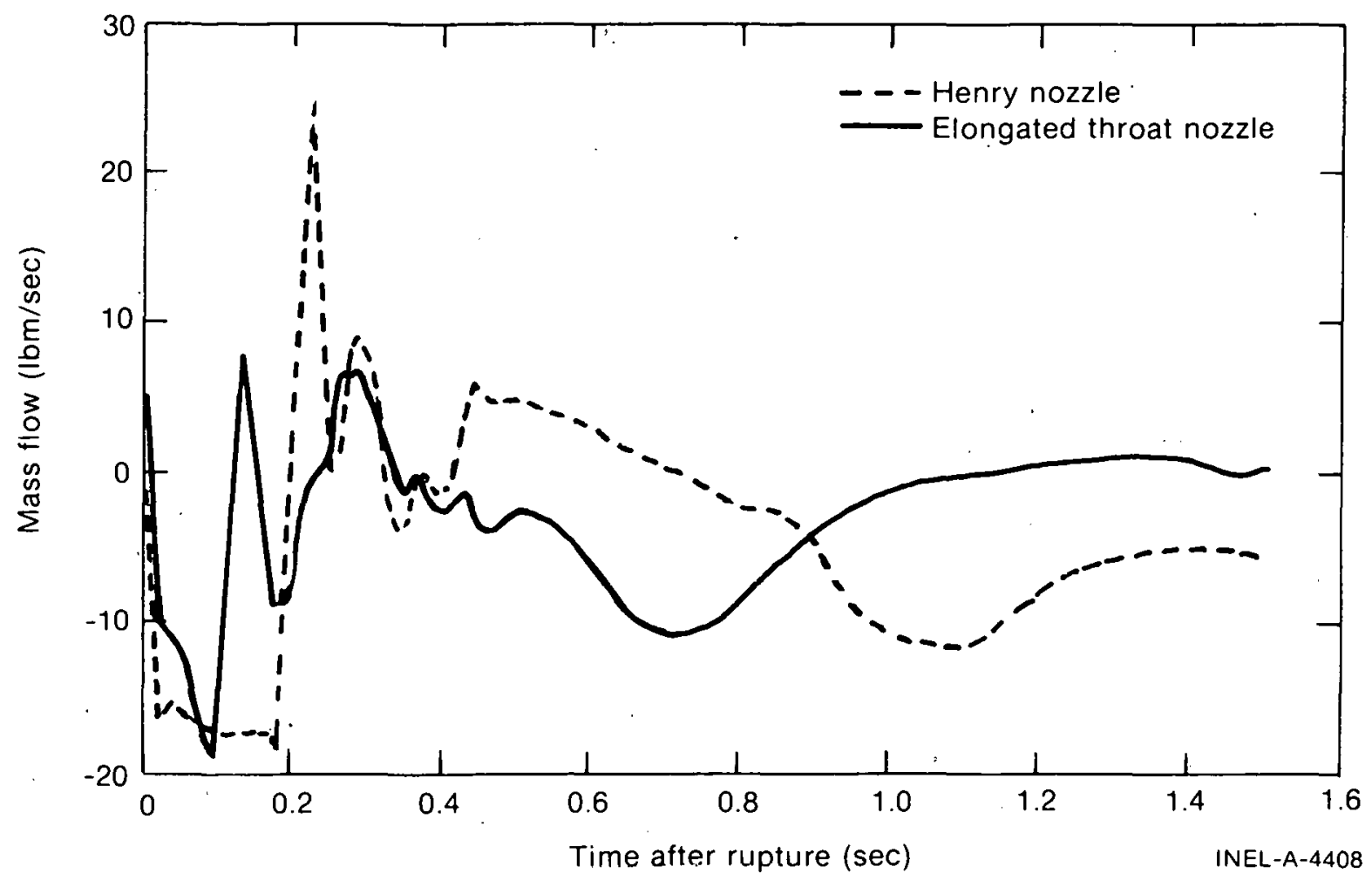

Fig. 18 RELAP4 calculation of mass flow in the core at the 52 -in. elevation.

Figure 19 shows the mass flow at the core inlet for the tests utilizing the Henry nozzle and the elongated throat. nozzle. This figure shows the greatest flow differences exist within $0.5 \mathrm{sec}$ of rupture. Figures 14 through 18, from the RELAP4 work, indicate that the significant differences in core behavior began less than $0.5 \mathrm{sec}$ following rupture.

The results of this evaluation confirm that the break nozzle configuration has significant effect on the break flow rate. The analysis given in the second part of this section indicatcs a consistent effect on core hydraulic and thermal response resulting in a large shift to earlier DNB behavior with the utilization of the elongated throat nozzle. 


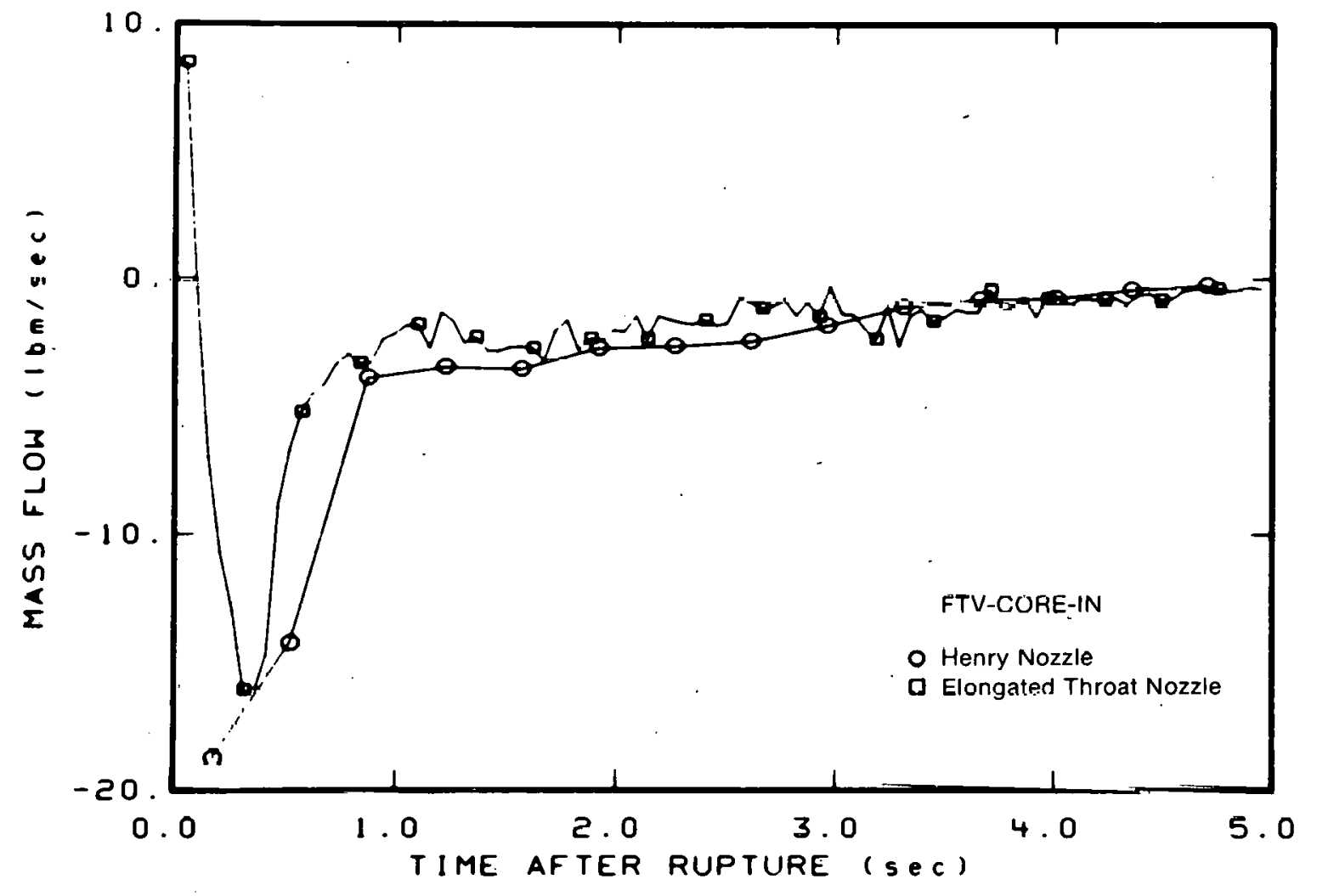

Fig. 19 Mass flow at the core inlet. 


\section{CONCLUSIONS}

An evaluation of the effect of two different break nozzle configurations on system response has been performed. This section summarizes the conclusions drawn from this study.

When tested under the same conditions, the elongated throat nozzle experienced a lower break flow rate than did the Henry nozzle geometry. The conclusion reached is that during subcooled blowdown the liquid was accelerated to a higher velocity in the Henry nozzle, which resulted in the higher flow rates. The fluid in the Henry nozzle was found to be operating in thermodynamic nonequilibrium until saturated blowdown began. However, apparently the fluid in the elongated throat nozzle was in thermodynamic equilibrium and a choking plane occurred near the end of the constant area throat.

The difference in break nozzle configuration also resulted in a difference in core hydraulic response. Utilization of the elongated throat nozzle resulted in a reduced core flow reversal relative to the Henry nozzle. The reduced core cooling due to this difference in core flow resulted in the rod thermal response shifting from $31 \%$ early DNB behavior with the Henry nozzle to $75 \%$ early DNB behavior with the elongated throat nozzle. Therefore, the conclusion reached was that DNB response is very sensitive to the magnitude of core flow reversal early in blowdown which is in turn sensitive to the behavior at the break.

The elongated throat nozzle was used in all subsequent LOFT counterpart tests as a result of the conclusions reached in this report. This nozzle also was chosen since the elongated throat nozzle was scaled from LOFT break nozzle geometry, and because the purpose of the LOFT counterpart tests was to supply the LOFT Program with pertinent data. 


\section{REFERENCES}

1. Quarterly Technical Report on Water Reactor Safety Programs Sponsored by the Nuclear Regulatory Commission's Division of Reactor Safety Research, January - March 1975, ANCR-1254 (September 1975) pp 29-60.

2. C. G. Bruch (ed.), RELAP4/MOD5, A Computer Program for the Transient Thermal-Hydraulic Analysis of Nuclear Reactors and Related Systems, Users Manual, ANCR-NUREG-1335 (September 1976).

3. E. M. Feldman and U. J. Olson, Serristule Mod-1 Program and System Description for the Blowdown Heat Transfer Tests (Series 2), ANCR-1230 (August 1975).

4. G. L. Sozzi and W. A. Sutherland, Critical Flow of Saturated and Subcooled Water at High Pressure, NEDO-13418 (July 1975).

5. H. K. Fauske, "The Discharge of Saturated Water Through Tubes," Chemical Engineering Progress Symposium Series, 61, 59 (1965) pp 210-216.

6. B. L. Collins, M. L. Patton Jr, K. E. Sackett, Experiment Data Report for Semiscale Mod-1 Test S-05-5 (Alternate ECC Injection Test), TREE-NUREG-1054 (April 1977). 
APPENDIX A

RELAP4 CORE MODEL DESCRIPTION 
THIS PAGE

\section{WAS INTENTIONALLY \\ LEFT BLANK}




\section{APPENDIX A}

\section{RELAP4 CORE MODEL DESCRIPTION}

The RELAP4 computer program $[A-1]$ was developed primarily to describe the blowdown transient behavior of water cooled nuclear reactors subjected to postulated accidents such as those resulting from loss-of-coolant. The model used in this analysis of LOFT counterpart data from Test S-06-5 and the ECC baseline Test S-04-6 was a RELAP4 core model shown in Figure A-1. Tables A-I and A-II describe the model volumes and junctions.

The model received boundary conditions from recorded test data. The heated section of the core was powered by heat fluxes to the core volumes based on heat generation rates calculated from test data. The interface with the intact loop vessel outlet is controlled by the mass flow rate and fluid enthalpy, both of which are derived from test results. At the broken loop vessel outlet the controlling variables are pressure and fluid quality, determined from test data, and at the core inlet the controlling variables are the mass flow rate and fluid enthalpy. 


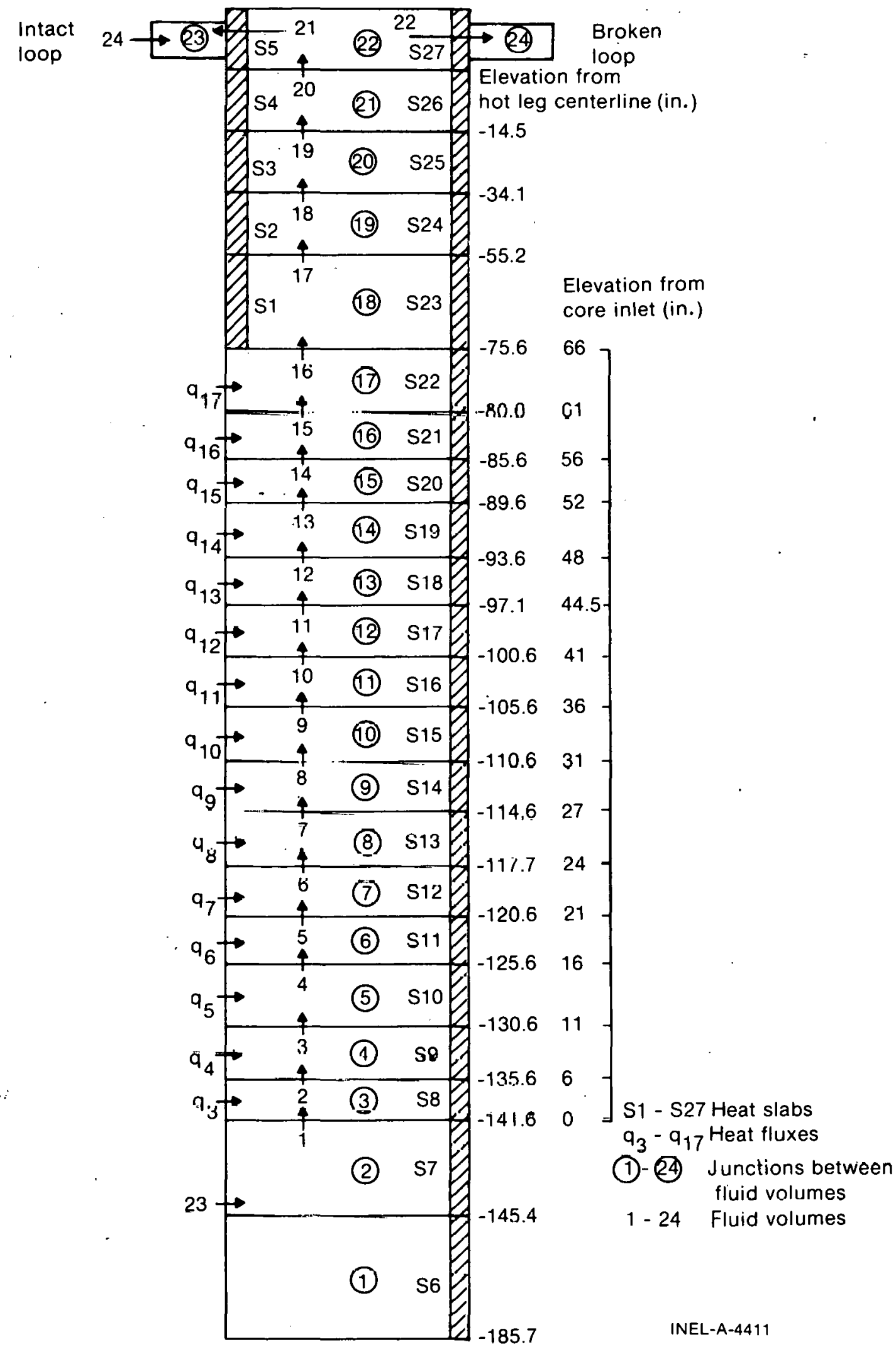

Fig. A-1 RELAP4 core model. 
TABLE A-I

RELAP4 CONTROL VOLUME DESCRIPTION

\begin{tabular}{cc}
\hline $\begin{array}{c}\text { Control Volume } \\
1,2\end{array}$ & $\frac{1}{\text { Description }}$ \\
3 through 17 & Cower plenum volume \\
18 through 22 & Upper plenum volume \\
23 & Intact loop volume \\
24 & Broken loop volume \\
\hline
\end{tabular}

TABLE A-II

RELAP4 JUNCTION ·DESCRIPTION

\begin{tabular}{cl}
$\frac{\text { Junction }}{23}$ & $\frac{1}{\text { Description }}$ \\
\hline 1 through 16 & Core inlet flow \\
17 through 20 & Upper plenum flow \\
21 & Flow from upper plenum \\
& to the intact loop \\
22 & Flow from upper plenum \\
& to the broken loop \\
24 & Mass flow from intact \\
& loop vessel outlet
\end{tabular}




\section{REFERENCE}

A-1. C. G. Bruch (ed.), RELAP4/MOD5, A Computer Program for the Transient Thermal-Hydraulic Analysis of Nuclear Reactors and Related Systems, Users Mariual, ANCR-NUREG-1335 (September 1976). 
DISTRIBUTION RECORD FOR TREE-NUREG 1118

Internal Distribution

1 - Chicago Patent Group 9800 South Cass Avenue

Argonne, Illinois 60439

2 - CA Benson

Idaho Operations Office-ERDA

Idaho Falls, ID 83401

3 - HP Pearson, Supervisor

Technical Information

4 - RJ Beers, ID

5 - PE Litteneker, ID

6 - RE Tiller, ID

7 - RE Wood, ID

8-17 - INFL Technical Library

18-37 - Authors

38-91 - Special Internal

External Distribution

92-93 - Saul Levinc, Director Office fo Nuclear Regulatory Research, NRC Washington, DC 20555

94-397 - Distribution under NRC-2, Water Reactor Safety Research Fuel Behavior. 